\title{
Simulation of High Impact Rainfall Events Over Southeastern Hilly Region of Bangladesh Using MM5 Model
}

\author{
M. N. Ahasan, ${ }^{1}$ M. A. M. Chowdhury, ${ }^{2}$ and D. A. Quadir ${ }^{3}$ \\ ${ }^{1}$ SAARC Meteorological Research Centre (SMRC), Dhaka-1207, Bangladesh \\ ${ }^{2}$ Department of Physics, Jahangirnagar University, Savar, Dhaka-1342, Bangladesh \\ ${ }^{3}$ Department of Physics, Uttara University, Mirpur-1, Dhaka-1216, Bangladesh
}

Correspondence should be addressed to M. N. Ahasan; nazmul_smrc@yahoo.com

Received 30 June 2013; Revised 10 September 2013; Accepted 18 November 2013

Academic Editor: Helena A. Flocas

Copyright (C) 2013 M. N. Ahasan et al. This is an open access article distributed under the Creative Commons Attribution License, which permits unrestricted use, distribution, and reproduction in any medium, provided the original work is properly cited.

\begin{abstract}
Simulation of high impact rainfall events over southeastern hilly region of Bangladesh has been carried out using Fifth-Generation PSU/NCAR Mesoscale Model (MM5) conducting two historical rainfall events, namely, 21 June, 2004 and 11 July, 2004. These extraordinary rainfall events were localized over the Rangamati region and recorded $304 \mathrm{~mm}$ and $337 \mathrm{~mm}$ rainfall on $21 \mathrm{June}$, 2004 and 11 July, 2004, respectively, over Rangamati within a span of $24 \mathrm{~h}$. The model performance was evaluated by examining the different predicted and derived parameters. It is found that the seasonal monsoon trough has northerly position compared to normal and pass through Bangladesh extending up to northeast India for both cases. The heat low was found to be intense $(996 \mathrm{hPa})$ with strong north-south pressure gradient $(12-15 \mathrm{hPa})$. The analysis of the geopotential height field at $200 \mathrm{hPa}$ shows that the Tibetan high is shifted towards south by $7-8^{\circ}$ latitudes with axis along $22-25^{\circ} \mathrm{N}$ for both cases. The analysis of the wind field shows that the areas of high impact rainfall exhibit strong convergence of low level monsoon circulation ( 19-58 knots). The strong southwesterlies were found to exist up to $500 \mathrm{hPa}$ level in both cases. The lower troposphere $(925-500 \mathrm{hPa})$ was characterized by the strong vertical wind shear $\left(\sim 9-18 \mathrm{~ms}^{-1}\right)$ and high relative vorticity $\left(\sim 20-40 \times 10^{-5} \mathrm{~s}^{-1}\right)$. The analysis also shows that the areas of high impact rainfall events and neighbourhoods are characterized by strong low level convergence and upper level divergence. The strong southwesterly flow causes transportation of large amount of moisture from the Bay of Bengal towards Bangladesh, especially over the areas of Rangamati and neighbourhoods. The high percentage of relative humidity extends up to the upper troposphere along a narrow vertical column. Model produced details structure of the spatial patterns of rainfall over Bangladesh reasonably well though there are some biases in the rainfall pattern. The model suggests that the highly localized high impact rainfall was the result of an interaction of the mesoscale severe convective processes with the large scale active monsoon system.
\end{abstract}

\section{Introduction}

Rangamati $\left(22.53^{\circ} \mathrm{N}, 92.20^{\circ} \mathrm{E}\right)$, the southeastern hilly city of Bangladesh (latitudes $20^{\circ} 34^{\prime}-26^{\circ} 38^{\prime} \mathrm{N}$ and longitudes $88^{\circ} 01^{\prime}-$ $92^{\circ} 41^{\prime} \mathrm{E}$ ), is situated on the western slopes of Mizo Hills and Arakan Mountains. Rangamati is very different in terms of topography from the rest of Bangladesh, as the city is built on the hilly regions. On 21 June, 2004 and 11 July, 2004, Rangamati received $304 \mathrm{~mm}$ and $337 \mathrm{~mm}$ rainfall within 24 hours respectfully (Figure 1). These unprecedented rainfall events were localized over Rangamati region (Figures 2(a) and 2(b)). This torrential rain disrupted life in the city by causing severe flash floods. In addition to the floods, the rains triggered devastating landslides in the deforested hills and caused loss of life and properties.

The heavy rainfall events become significant in human affairs when they are combined with other hydrological elements. The problem of forecasting heavy precipitation is especially difficult since it involves creating a quantitative precipitation forecast, recognized as a challenging task [1]. Simulation of active mesoscale systems such as western disturbances, severe thunderstorms, tropical cyclones, and heavy rainfall episodes during active monsoon season, with high-resolution mesoscale models such as the FifthGeneration PSU/NCAR Mesoscale Model (MM5), has been attempted by many researchers (e.g., [2-11]). Application of 


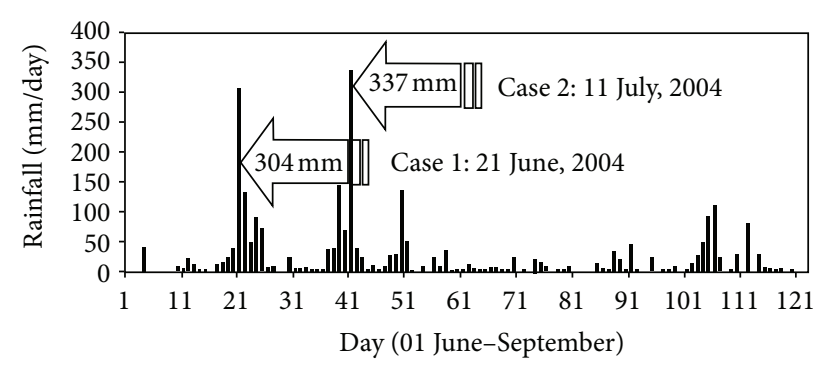

FIGURE 1: Temporal distribution of daily observed rainfall at Rangamati, Bangladesh, during summer monsoon 2004. The high impact rainfall events are indicated by arrow sign.

NWP model in monsoon weather research and forecasting is very little in Bangladesh due to limitation of computing platform and technical knowledge. In spite of the limitations, some works have been done on heavy rainfall during summer monsoon season of Bangladesh using NWP model (e.g., [1218]) which are summarized below.

Prasad [12] has carried out the study entitled "Monsoon forecasting with a limited area numerical weather prediction systems." He identified some heavy rainfall events from the summer monsoon season of 1987, 1997, and 2002 over Bangladesh and northeast India. He investigated the synoptic situations responsible for causing the heavy rainfall using FSU limited area model and he also forecasted the events.

Islam [13] has studied summer monsoon rainfall using regional climate model PRECIS. The model-simulated rainfall was compared with BMD observed rainfall and developed a calibration technique to match the model-simulated rainfall with observed rainfall.

Das [14] has carried out a research work on "Studies of tornadic storms over Bangladesh using Radar and WRF model." He selected several unusual tornadic storms cases during Aug-Sep 2008 which caused loss of lives and properties. He studied the synoptic features responsible for occurring such unusual storms during monsoon season by using Radar data and WRF mesoscale model.

Ahasan et al. [15-18] have studied some cases (e.g., 11 June, 2007, 14 September, 2004, 07 September, 2011, etc.) on heavy rainfall over Bangladesh using MM5 and WRF model for understanding the synoptic situations and developing the prediction techniques.

The present study has been undertaken to simulate the high impact rainfall events which occurred over Rangamati, Bangladesh, conducting two events on 21 June, 2004 and 11 July, 2004 using the MM5 model. The main objective of the study is to test the MM5 model in simulation of high impact rainfall events. The secondary objective of the study is to identify the atmospheric conditions, which triggered and maintained such events.

\section{Data Used, Model Experimental Setup, and Methodology}

The Fifth-Generation PSU/NCAR Mesoscale model [19, 20] version 3.7 as adopted for real-time mesoscale weather research and simulation at SAARC Meteorological Research Centre (SMRC), Dhaka, Bangladesh, has been used for this study. The data used, experimental setup of the model, and methodology of the study are provided in this section.

2.1. Data Used. The NCEP high-resolution global final (FNL) analysis data on $1.0^{\circ} \times 1.0^{\circ}$ grids covering the entire globe every $6 \mathrm{~h}$ were used for model initialization and as lateral boundary conditions. The USGS topographic data GTOPO30 (interpolated depending on resolution) were used as earth surface topography and 25 Categories USGS data were used as vegetation/land use. The 5-layer soil moisture data were used as land surface processes.

The daily $0.25^{\circ} \times 0.25^{\circ}$ resolution TRMM 3B $42 \mathrm{~V} 6$ rainfall data have been downloaded from their website (ftp://disc2 .nascom.nasa.gov/data/TRMM/Gridded/Derived_Products/ 3B42_V6/Daily/) to justify the model-simulated rainfall structure, development time, and location. Moreover, daily observed rainfall data of 34 meteorological stations of Bangladesh have been collected from the archive of Bangladesh Meteorological Department (BMD) to validate the model derived rainfall.

2.2. Model Experimental Setup and Methodology. For the present study, the model was run on triple-nested domains at 45,15 , and $5 \mathrm{~km}$ resolutions using Anthes-Kuo parameterization scheme [21] based on 0000 UTC of 20 June, 2004 and 10 July, 2004 (more than $24 \mathrm{~h}$ before of the event) initial conditions. The triple nested domains configured in MM5 model for the study are shown in Figure 3. Domain 1 (D1) is the coarsest mesh and has $120 \times 105$ grid points in the northsouth and east-west directions, respectively, with a horizontal grid spacing of $45 \mathrm{~km}$. Within the domain D1, domain 2 (D2) is nested with $100 \times 94$ grid points at $15 \mathrm{~km}$ grid spacing. The fine-mesh domain 3 (D3) is $151 \times 115$ points with $5 \mathrm{~km}$ grid spacing. Bangladesh is the main focus area in this study. The model uses two-way nesting, where coarse grid data are interpolated to finer grid boundaries and the finer grid provides updated data to the coarse grid. All these 3 domains are centered at $20^{\circ} \mathrm{N}, 90^{\circ} \mathrm{E}$ over Bangladesh to represent the regional-scale circulations and to extract the complex meteorological features in the synoptic and subsynoptic scales. All these domains were configured to have the same vertical structure of 23 unequally spaced nondimensional pressure levels in the sigma coordinate. The other physical parameterization schemes used in this study are the medium range forecast (MRF) scheme for a planetary boundary layer [22], simple ice for an explicit moisture scheme [23], simple cooling as radiation scheme, and five-layer soil model as land surface processes.

\section{Results and Discussion}

The synoptic situations responsible for producing these extraordinary high impact rainfall events of 21 June, 2004 and 11 July, 2004 over Rangamati have been analyzed by using MM5 model results. The analysis of the different meteorological fields and some of the derived parameters are presented in 


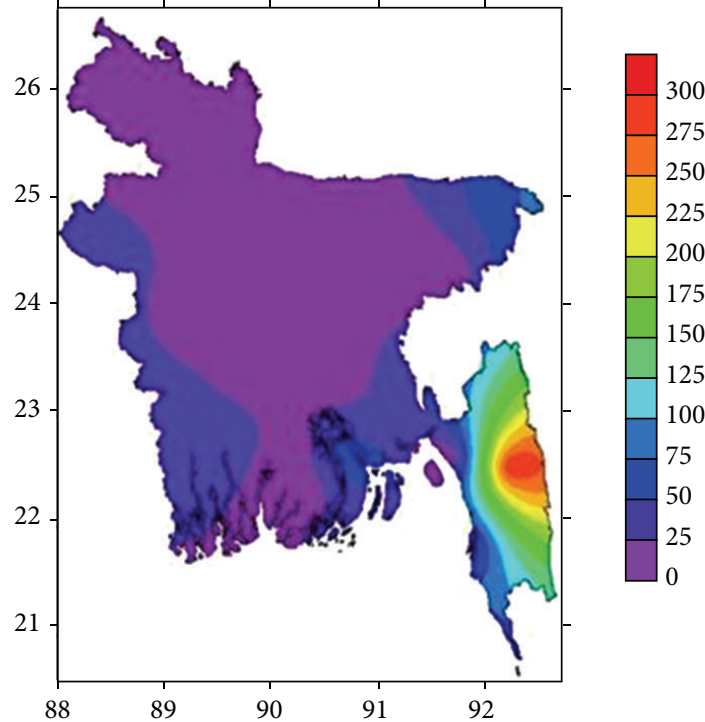

(a)

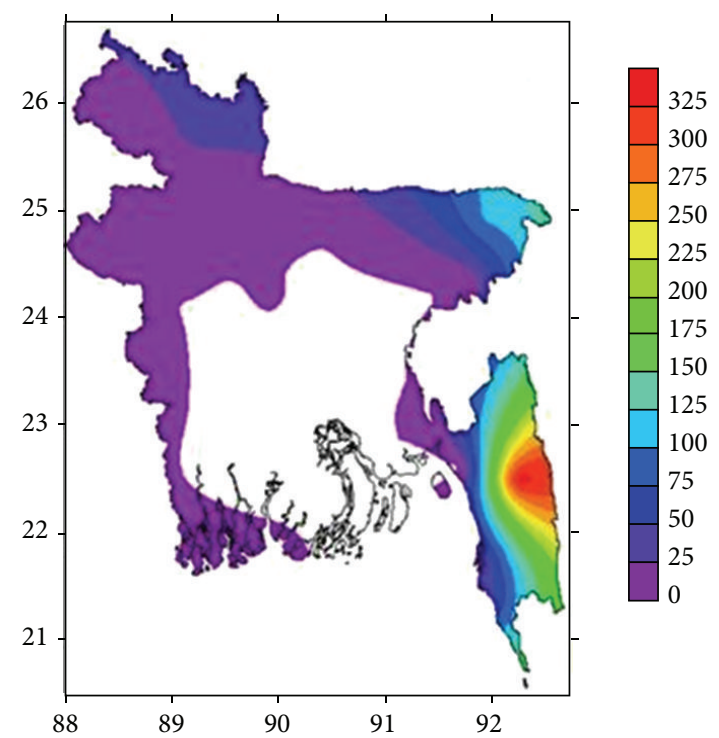

(b)

FiguRE 2: Spatial distribution of rainfall (mm) over Bangladesh on 21 June, 2004 (a) and 11 July, 2004 (b). The high impact rainfall events over Rangamati $\left(22.53^{\circ} \mathrm{N}, 92.20^{\circ} \mathrm{E}\right)$ are clearly seen in both figures.

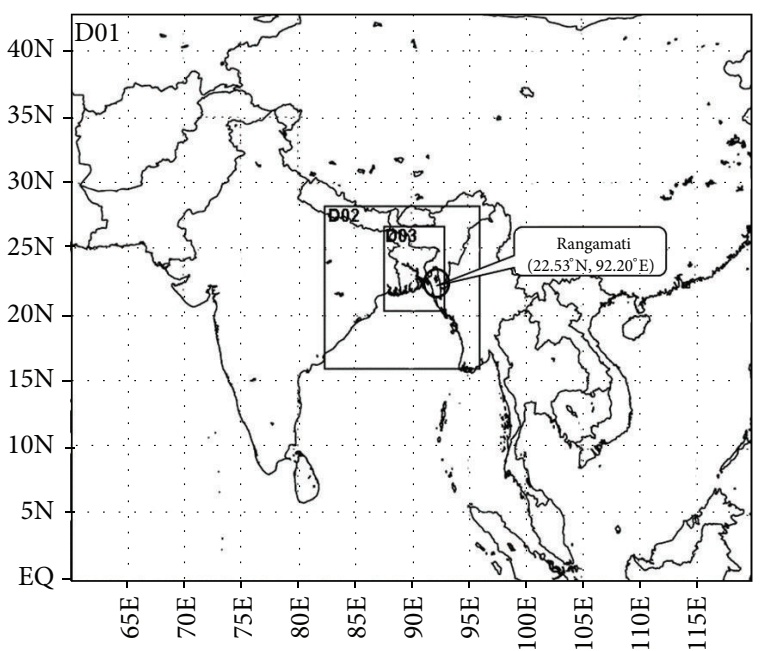

FIGURE 3: Triple nested domains in MM5 model. The position of Rangamati $\left(22.53^{\circ} \mathrm{N}, 92.20^{\circ} \mathrm{E}\right)$ is indicated by black circle.

the Figures 4-11 (for case 1) and Figures 12-19 (for case 2) and discussed accordingly.

\subsection{Case 1: 21 June, 2004}

3.1.1. Mean Sea Level Pressure. Model-simulated mean sea level pressure $(\mathrm{hPa})$ for D1 domain, valid for 00 UTC of 21 June, 2004, is presented in Figure 4. The figure shows the eastwest running monsoon trough which is positioned close to the foot hills of the Himalayas. This is a well-known situation of "break monsoon" condition over central India and active monsoon condition over Bangladesh and nearby territory of north, northeast India and Bhutan [24] which seems to be

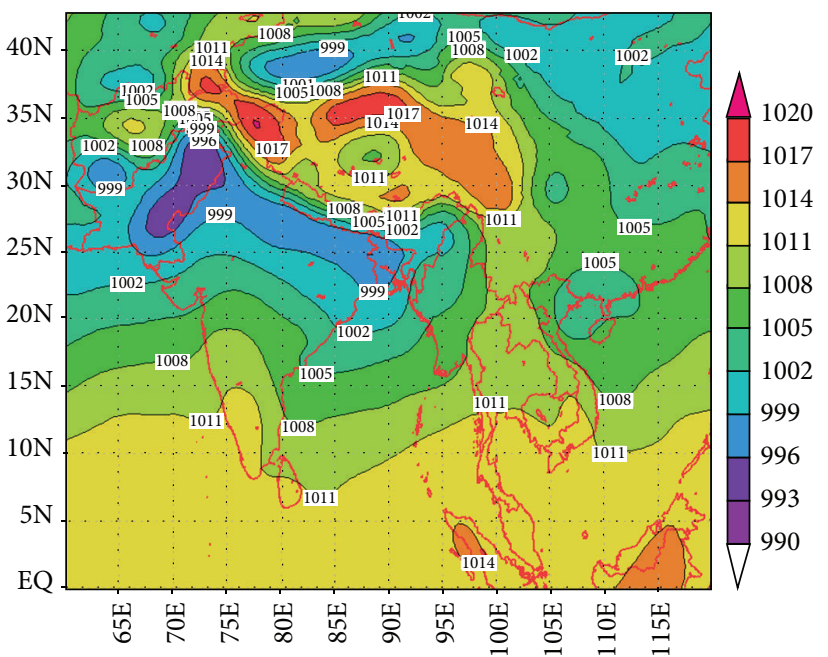

FIGURE 4: Mean sea level pressure (hPa), valid for 00 UTC of 21 June, 2004 over South Asia.

a prominent feature responsible for this event. One branch of this seasonal monsoon trough runs towards the northeast India through the northeast Bangladesh, which is favourable for heavy rainfall over the southeast region (Rangamati) of the country and neighbourhoods.

The heat low over Pakistan is strong. The pressure at the centre of the heat low is about $996 \mathrm{hPa}$ and that over the southern part of India is about $1011 \mathrm{hPa}$. Monsoon flow is relatively strong due to this north-south pressure gradient. The above synoptic features provided favourable conditions for developing the severe mesoscale convections resulting in heavy rainfall over the areas of southeast Bangladesh. 


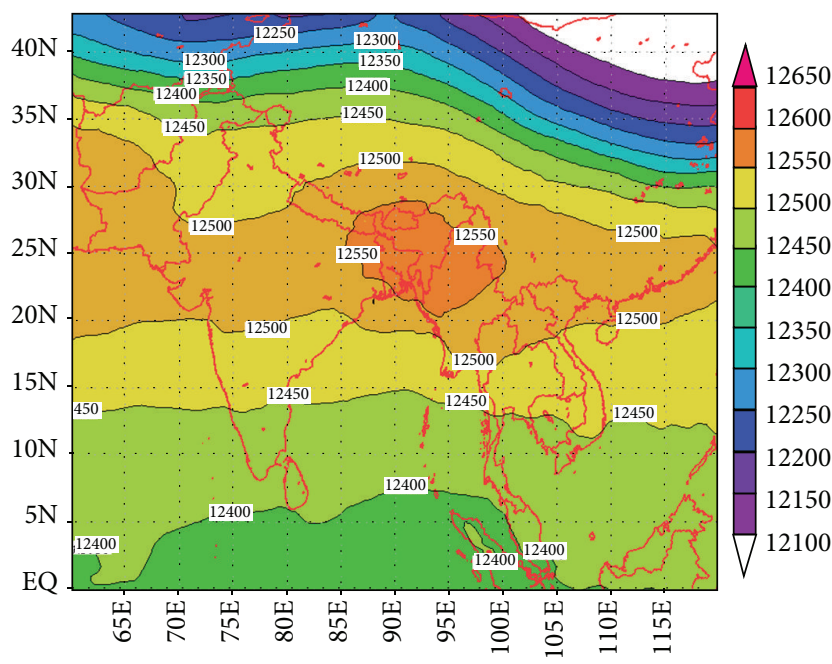

FIGURE 5: Geopotential height (m) at $200 \mathrm{hPa}$ level, valid for $00 \mathrm{UTC}$ of 21 June, 2004 over South Asia.

3.1.2. Geopotential Height Field at $200 \mathrm{hPa}$ Level. The geopotential height field at $200 \mathrm{hPa}$ level for 21 June, 2004 at 00 UTC has been shown in Figure 5. It is found that the high pressure zone is shifted towards the south than the normal position. The axis of the high pressure zone lies along $25^{\circ} \mathrm{N}$. The model generated structure and position of the $200 \mathrm{hPa}$ geopotential height field deviate to a large extend towards south ( $7-8^{\circ}$ latitudes) from its climatological normal position.

3.1.3. Lower and Upper Level Wind Field. The distribution of low level wind at $925 \mathrm{hPa}$ and $850 \mathrm{hPa}$ level and mid-level and upper level wind at $500 \mathrm{hPa}$ and $200 \mathrm{hPa}$ level valid for 06 UTC of 21 June, 2004 has been presented in Figures 6(a)$6(d)$. The prominent feature is a strong southwesterly low level flow transporting moisture from the Bay of Bengal into southeast Bangladesh (Figures 6(a) and 6(b)). A jet streak of about $30 \mathrm{~ms}^{-1}$ (58 knots) over southeast Bangladesh and its neighbourhood is a prominent feature marking the strong vertical wind shear in the lower troposphere (Figures 6(a) and 6(b)). A cyclonic circulation is seen in the lower level centering over the northwestern Bangladesh which extends up to the $500 \mathrm{hPa}$ level or more, exhibiting the fact that monsoon circulation is dominant up to the mid troposphere (Figure 6(c)). In the $200 \mathrm{hPa}$ level wind field, it is seen that the traditional large scale anticyclonic flow does not exist. The anticyclonic field is found to be broken with one strong out flow zone over the southeastern Bangladesh and its vicinities and another anticyclonic weak zone over India (Figure 6(d)).

3.1.4. Vertical Wind Shear. Vertical wind shear is an important dynamical factor in the development of convective systems in the form of thunderstorms and tornadoes. Vertical wind shear of the $u$ component of wind $\left(\mathrm{ms}^{-1}\right)$ in the lowest $6 \mathrm{~km}$ of the atmosphere $(500-925 \mathrm{hPa})$ at 06 UTC of 21 June, 2004 is presented in Figure 7. It is found that the southeast region of Bangladesh and neighbourhoods was characterized by the strong vertical wind shear. A core of strong wind shear of the order of $15-18 \mathrm{~ms}^{-1}$ may be seen in the southeast part of Bangladesh and neighbourhood is prominent.

3.1.5. Low Level Relative Vorticity. The low level relative vorticity field at $925 \mathrm{hPa}$ level valid for 06 UTC of 21 June, 2004 is presented in Figure 8. It is found that an elongated vorticity maximum of the order of $30-40 \times 10^{-5} \mathrm{~s}^{-1}$ was observed across the southeast region (Rangamati) of Bangladesh and neighbourhoods.

3.1.6. Low Level Convergence and Upper Level Divergence. Low level convergence and upper level divergence are the important parameters to analyze the convection systems. The distribution of divergence at $925 \mathrm{hPa}$ and $200 \mathrm{hPa}$ level is shown in Figures 9(a) and 9(b). The positive value indicates divergence and negative value indicates convergence. A welldefined area of low level convergence of the order of $-25 \times$ $10^{-5} \mathrm{~s}^{-1}$ over the southeast region (Rangamati region) of the country is clearly seen in the figure (Figure 9(a)). Sea level pressure (Figure 4) and low level wind patterns (Figures 6(a) and 6(b)) also indicate the convergence over the southeast Bangladesh (i.e., Rangamati). The intersection of the area of convergence by the southwesterly low level wind is a significant feature favourable for severe convective activity. This strong low level convergence associated with strong outflow (divergence) in the high level $(200 \mathrm{hPa})$ (Figures 6(d) and 9(b)) has provided favourable conditions for strong convection and production of very high rainfall.

3.1.7. Relative Humidity. Spatial distribution of relative humidity at 00 UTC of 21 June, 2004 is presented in Figure 10(a). It is found that the magnitude of humidity is very high over the southeast and north of Bangladesh. The circulation of southwesterly low level flow transports plentiful moisture from the Bay of Bengal to the areas of southeast Bangladesh and its neighbourhoods (Figures 6(a) and 6(b)). It is seen that the high humidity spreads over a large area of the Bay of Bengal which converges along a narrow zone in and around Rangamati. This convergence of moisture field enforces the air to rise up causing convection over this area. The vertical profile of the relative humidity field at 00 UTC of 21 June, 2004 along the longitude $92.20^{\circ} \mathrm{E}$ passing across Rangamati is presented in Figure 10(b). It is found that the vertical extent of high humidity reaches up to $350 \mathrm{hPa}$ over Rangamati along a wide vertical column of the troposphere. This clearly indicates the vertical growth of the convective system that produced the rainfall of high intensity.

3.1.8. Rainfall. The MM5-model-simulated $24 \mathrm{~h}$ accumulated rainfall on 21 June, 2004 for domain 3 at $5 \mathrm{~km}$ resolution is shown in Figure 11(a). The model derived rainfall was compared with the TRMM 3B42V6 observed rainfall which is shown in Figure 11(b). It is found that the high rainfall values are seen in the vicinity of the southeast region of Bangladesh (Figure 11(a)). It is also found that the model-simulated rainfall $(72.03 \mathrm{~mm})$ overestimated the TRMM observed rainfall 


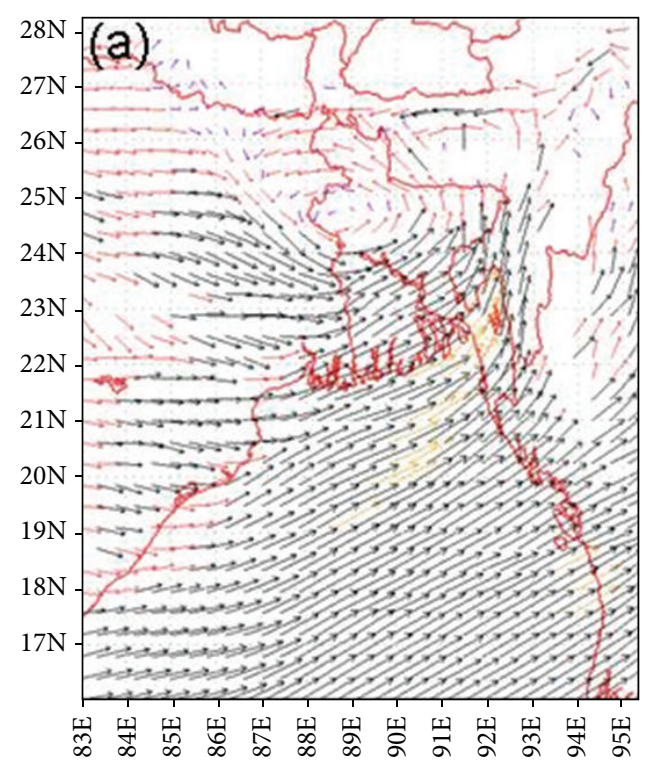

$\overrightarrow{20}$

(a)

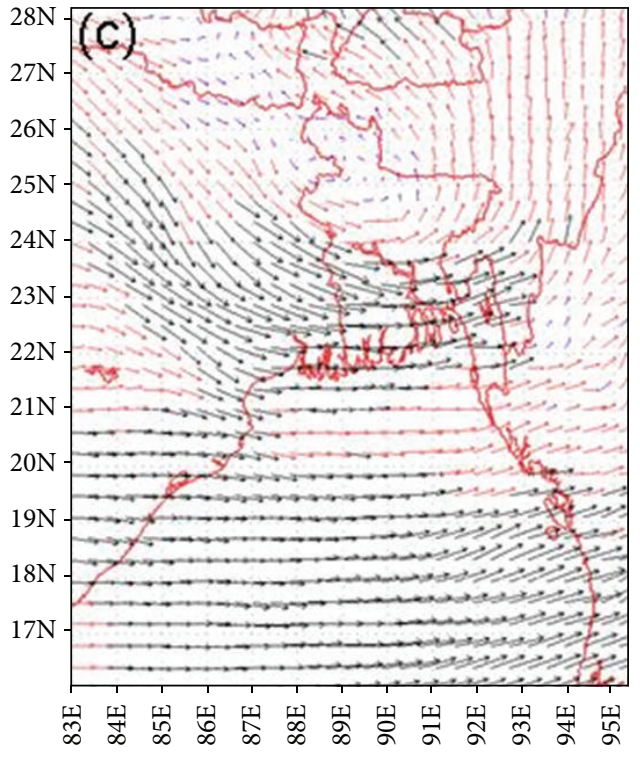

$\overrightarrow{20}$

(c)

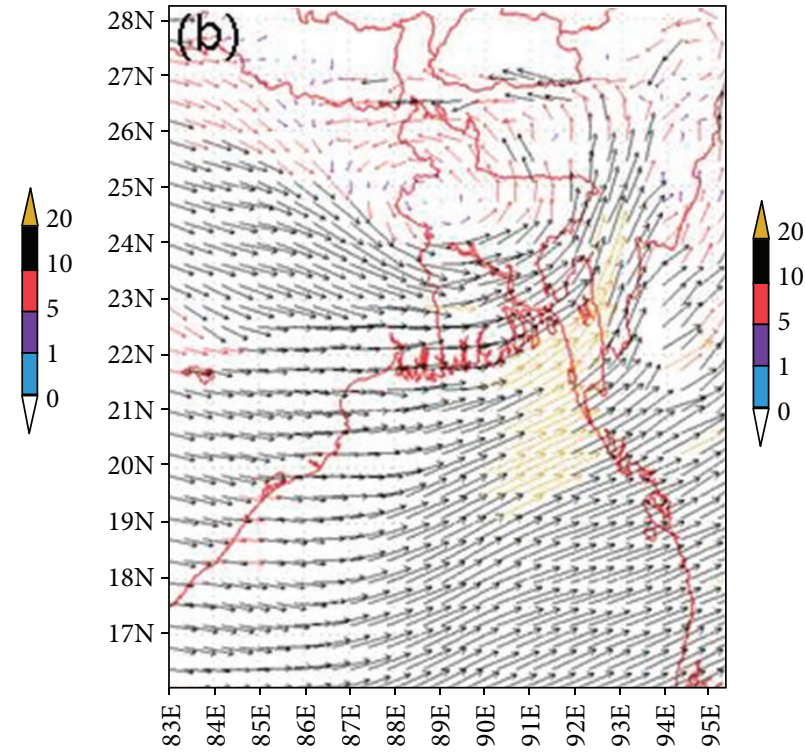

$\overrightarrow{20}$

(b)

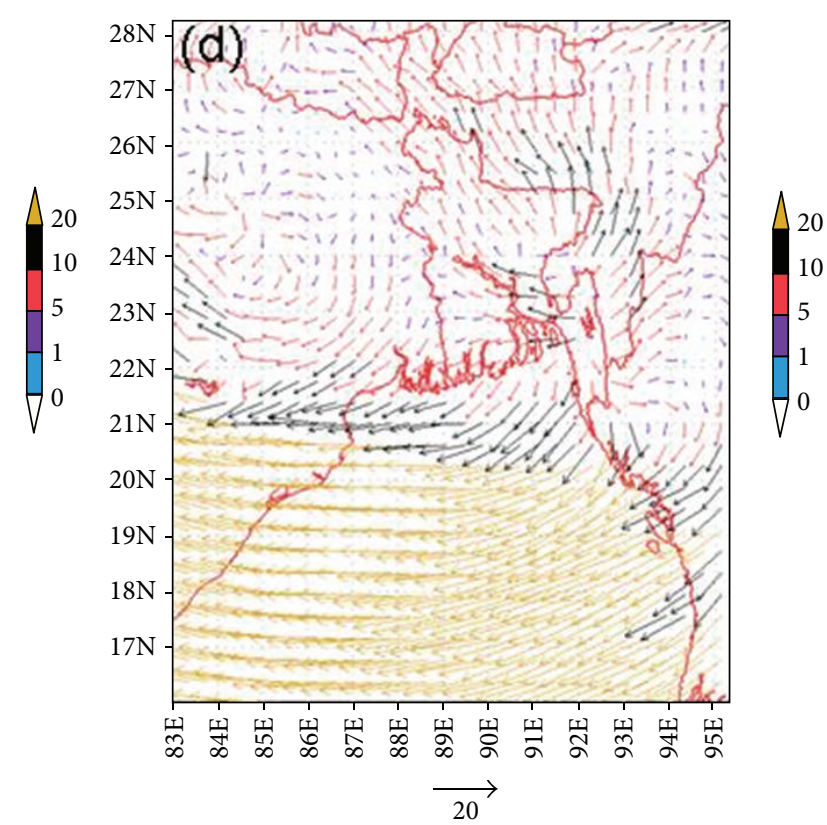

(d)

Figure 6: Wind field $\left(\mathrm{ms}^{-1}\right)$ analysis valid for 06 UTC of 21 June, 2004 at $925 \mathrm{hPa}(\mathrm{a}), 850 \mathrm{hPa}(\mathrm{b}), 500 \mathrm{hPa}(\mathrm{c})$, and $200 \mathrm{hPa}$ (d) over South Asia.

(64.04 $\mathrm{mm}$ ) by $11.09 \%$ though the MM5 model captured the location and structure of the studied case reasonably well. It seems that the intensity of the model-simulated accumulated rainfall is higher than the same observed by TRMM. It may be noted here that TRMM underestimated the monsoon rainfall over Bangladesh [25]; thus, the actual rainfall may be higher than the observed rainfall by TRMM. That is why the MM5 model-simulated rainfall seems to be realistic.

\subsection{Case 2: 11 July, 2004}

3.2.1. Mean Sea Level Pressure. Model-simulated mean sea level pressure $(\mathrm{hPa})$ at $00 \mathrm{UTC}$ of 11 July, 2004 is presented in Figure 12. The prominent feature of the mean sea level pressure is an elongated trough of low pressure running across the Gangetic plains over north India and extending towards the heat low in northwest India and Pakistan. The said elongated trough of low pressure is known as seasonal 


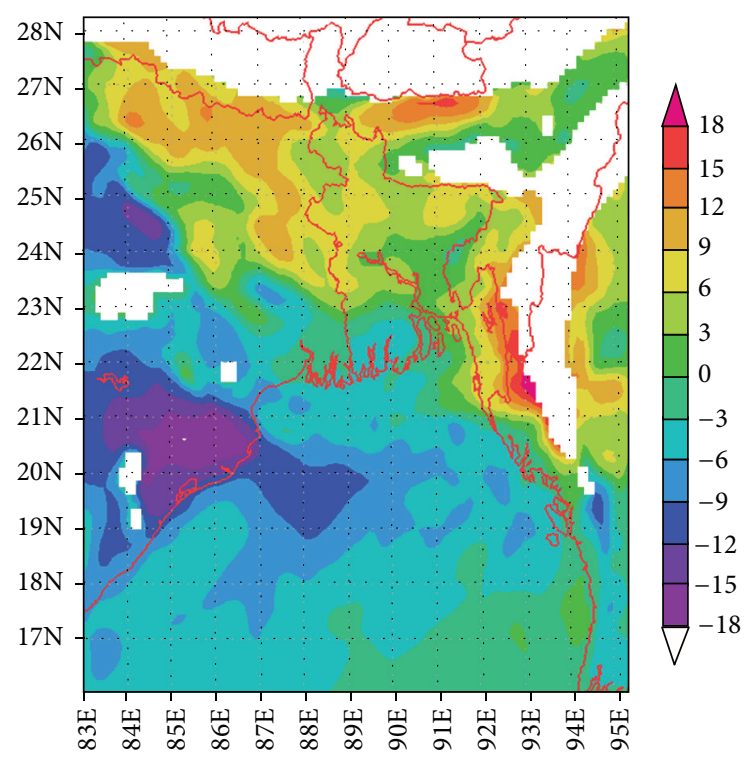

FIGURE 7: Vertical wind shear of the u component of wind $\left(\mathrm{ms}^{-1}\right)$ in the lowest $6 \mathrm{~km}$ of the atmosphere $(500-925 \mathrm{hPa})$, valid time for 06 UTC of 21 June, 2004 over South Asia.

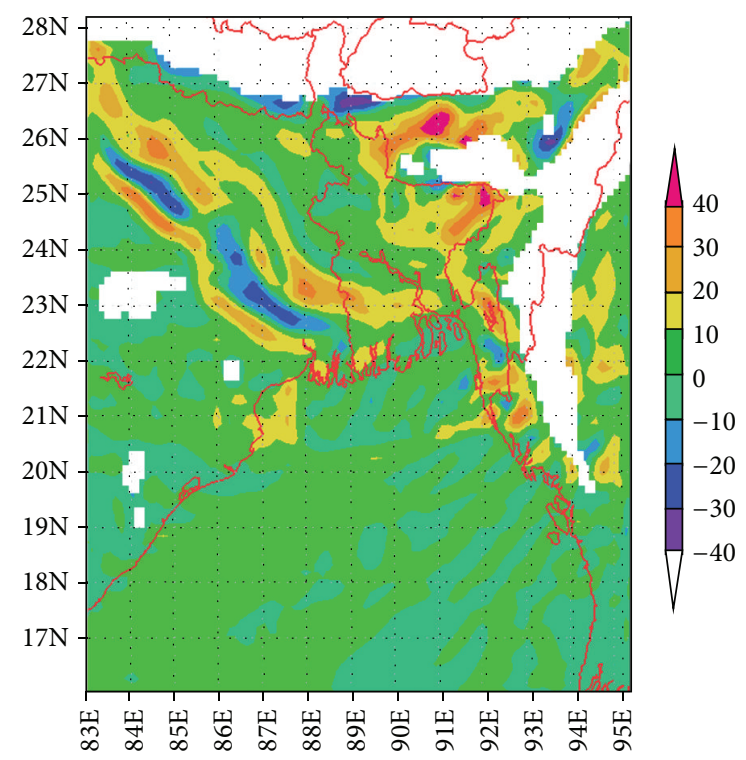

FIGURE 8: Low level relative vorticity (unit: $\times 10^{-5} \mathrm{~s}^{-1}$ ) at $925 \mathrm{hPa}$ valid for 06 UTC of 21 June, 2004 over South Asia.

monsoon trough. In the eastern side the trough extends up to northeast India through Bangladesh. For this case, monsoon trough is not as intense as the previous one. Its position is slightly northern than the normal position which indicates the so called "break monsoon" condition over the central part of India. The heat low over Pakistan is also less intense than the normal. The pressure at the centre of the heat low is about $996 \mathrm{hPa}$ and that over the southern part of India is around $1008 \mathrm{hPa}$. Monsoon flow is moderately intense due to this north-south pressure gradient $(12 \mathrm{hPa})$. The isobars over the Bay of Bengal have an almost southwest to northeast orientation over the Bay of Bengal.
3.2.2. Geopotential Height Field at $200 \mathrm{hPa}$ Level. The geopotential height field at $200 \mathrm{hPa}$ level for $11 \mathrm{July,} 2004$ at 00 UTC has been shown in Figure 13. It is seen that the high pressure zone lies over the vast area of Bangladesh, northeast India, and Bhutan. A tongue of the intense high pressure zone extends towards the southeast part of the country where high impact rainfall had occurred. The axis passes along $25^{\circ} \mathrm{N}$. It is also seen that a large trough in upper air westerlies lies over the northeast part of the domain.

3.2.3. Lower and Upper Level Wind Field. The distribution of model-simulated low level wind at $925 \mathrm{hPa}$ and $850 \mathrm{hPa}$ and mid-level and upper level wind at $500 \mathrm{hPa}$ level and $200 \mathrm{hPa}$ at 00 UTC of 11 July, 2004 are presented in Figures 14(a)-14(d). The southwesterly wind prevails over the southeast regions of Bangladesh and the area of convergence is clearly seen over Rangamati and neighbourhoods (Figures 14(a) and 14(b)). The wind speed of about $10 \mathrm{~ms}^{-1}$ (19 knots) prevails over the southeast Bangladesh and adjoining areas (Figure 14(c)). The southwesterly and westerly are persistent at $500 \mathrm{hPa}$ level over most parts of Bangladesh. A zone of strong outflow is seen over the southeast part of the country and its neighbourhoods where high impact rainfall event had occurred (Figure 14(d)).

3.2.4. Vertical Wind Shear. Vertical wind shear of the u component of wind $\left(\mathrm{ms}^{-1}\right)$ in the lowest $6 \mathrm{~km}$ of the atmosphere (500-925 hPa), valid time for 06 UTC of 11 July, 2004, is presented in Figure 15. It is found that the environment of Rangamati and neighbourhoods was characterized by the strong vertical wind shear. A core of strong shear of the order of 6-9 $\mathrm{ms}^{-1}$ may be seen in the southeast of Bangladesh and neighbourhoods.

3.2.5. Low Level Relative Vorticity. The relative vorticity field at $925 \mathrm{hPa}$ level valid for 06 UTC of 11 July, 2004 is presented in Figure 16. The relative vorticity field shows vorticity maximum of the order of $20-30 \times 10^{-5} \mathrm{~s}^{-1}$ across the northwest and $10-20 \times 10^{-5} \mathrm{~s}^{-1}$ across the southeast Bangladesh (Rangamati) and neighbourhoods.

3.2.6. Low Level Convergence and Upper Level Divergence. The distribution of divergence at $925 \mathrm{hPa}$ (a) and $200 \mathrm{hPa}$ (b) valid for 06 UTC of 11 July, 2004 is shown in Figures 17(a) and $17(\mathrm{~b})$. An area of low level convergence with maximum over the southeast region of Bangladesh is clearly seen. The cutting across of the southwesterly low level wind and the convergence line/area (south, central-east, and southeast) is significant from the point of view of severe convective activity. A well-defined area of upper level divergence of the order of $20-25 \times 10^{-5} \mathrm{~s}^{-1}$ is the prominent over the same area (Figure 17(b)).

3.2.7. Relative Humidity. Spatial distribution of relative humidity and vertical profile of relative humidity at 00 UTC of 11 July, 2004 are presented in Figures 18(a) and 18(b). 


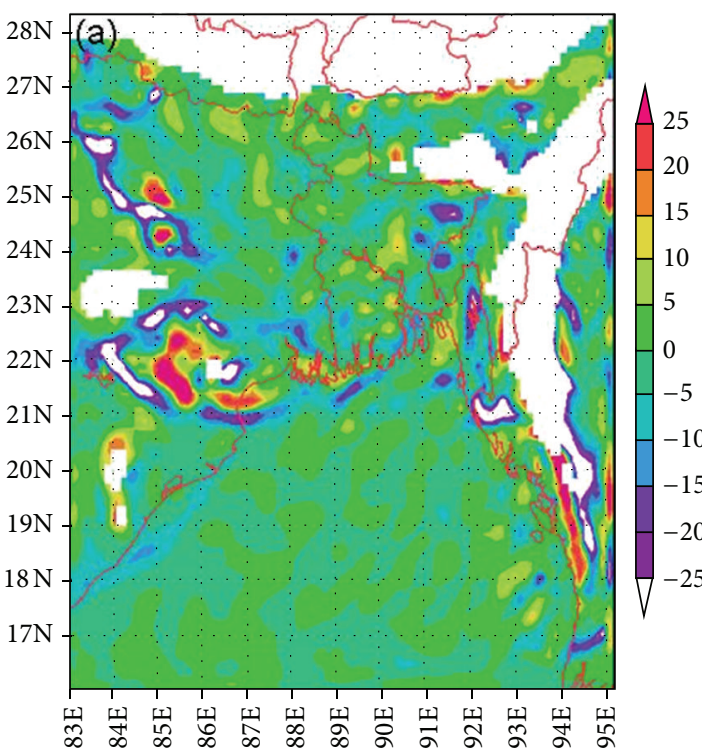

(a)

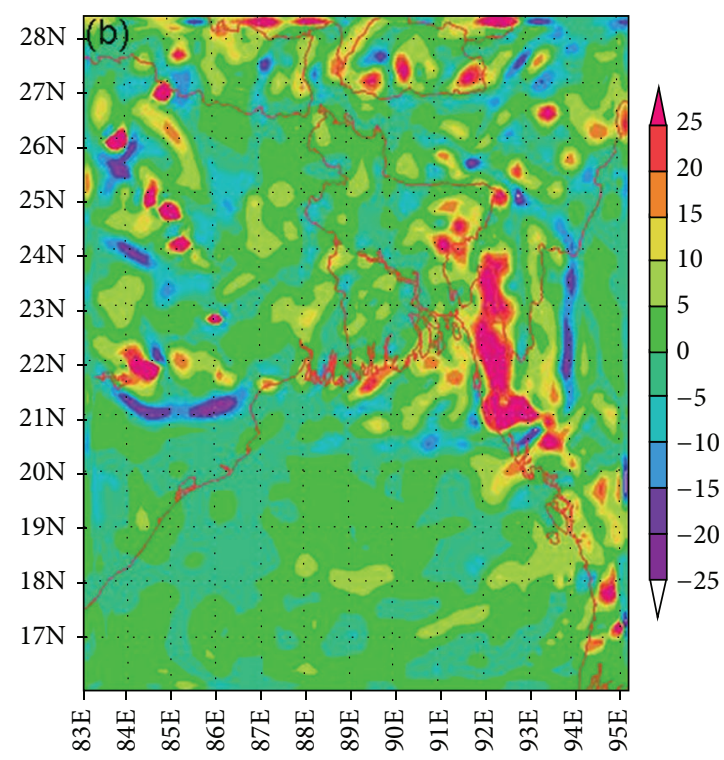

(b)

Figure 9: Distribution of divergence field (unit: $\times 10^{-5} \mathrm{~s}^{-1}$ ) valid for 06 UTC of 21 June, 2004 at $925 \mathrm{hPa}$ (a) and $200 \mathrm{hPa}$ (b) over South Asia.

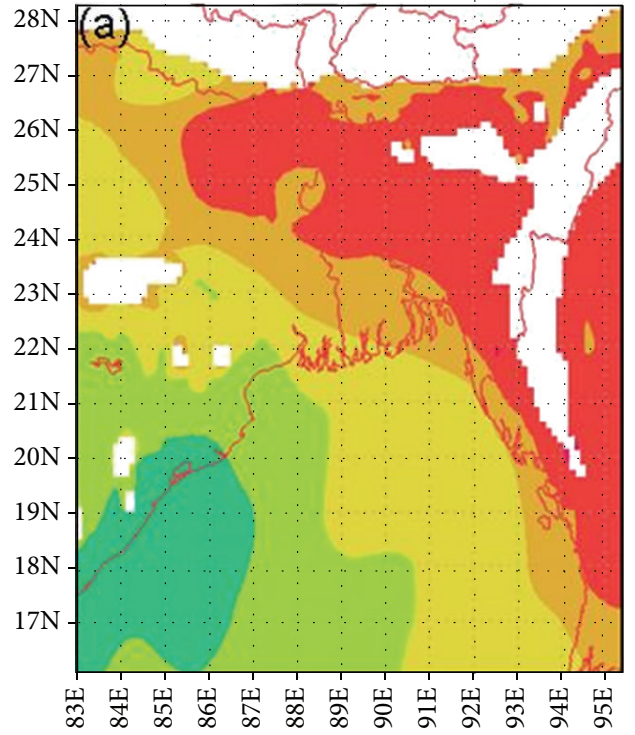

(a)

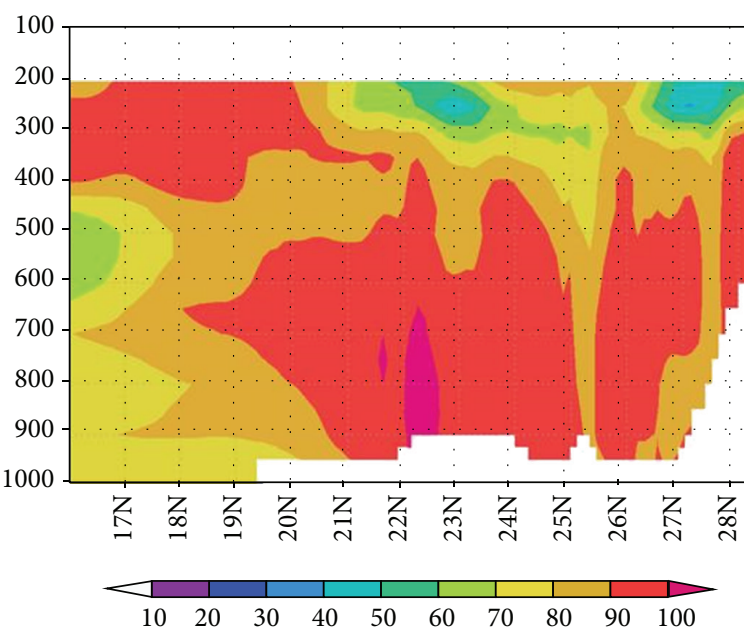

(b)

FIGURE 10: Distribution of relative humidity at $925 \mathrm{hPa}$ (a) and vertical profile of relative humidity along the longitude of Rangamati ( $92.20^{\circ} \mathrm{E}$ ), Bangladesh (b), valid for 00 UTC of 21 June, 2004 over South Asia.

The figure shows the high values of humidity of the order of $90-100 \%$ prevailing over the eastern part of Bangladesh (Figure 18(a)). It also shows that the high value of humidity is continuous pumping from the south towards the areas of Rangamati where high impact rainfall had occurred through a narrow area. The E-W vertical profile of the relative humidity field along $22.53^{\circ} \mathrm{N}$ latitude (position of Rangamati) is shown in Figure 18(b). It is found that the intensity of vertical profile of the relative humidity field extend up to $200 \mathrm{hPa}$ over Rangamati and neighbourhoods.
3.2.8. Rainfall. The MM5-model-simulated $24 \mathrm{~h}$ accumulated rainfall on 11 July, 2004 for domain 3 at $5 \mathrm{~km}$ resolution is shown in Figure 19(a). The model derived rainfall was compared with the TRMM 3B42V6 observed rainfall which is shown in Figure 19(b). It is found that the high rainfall values are seen in the vicinity of southeast Bangladesh. It is found that the model-simulated rainfall using AK cumulus parameterization scheme with MRF PBL fairly overestimated the TRMM by $24 \%$. However, the MM5 model captured well the location and structure of the studied case. It seems that 


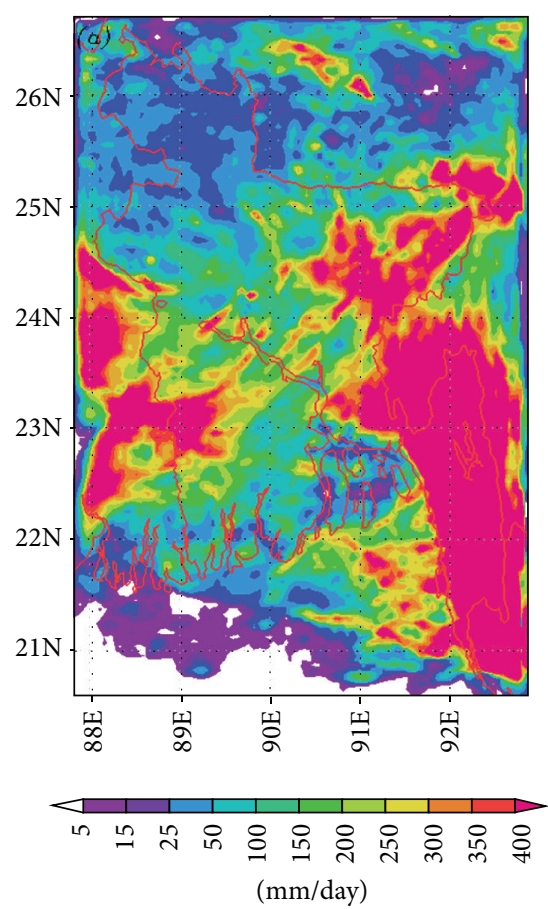

(a)

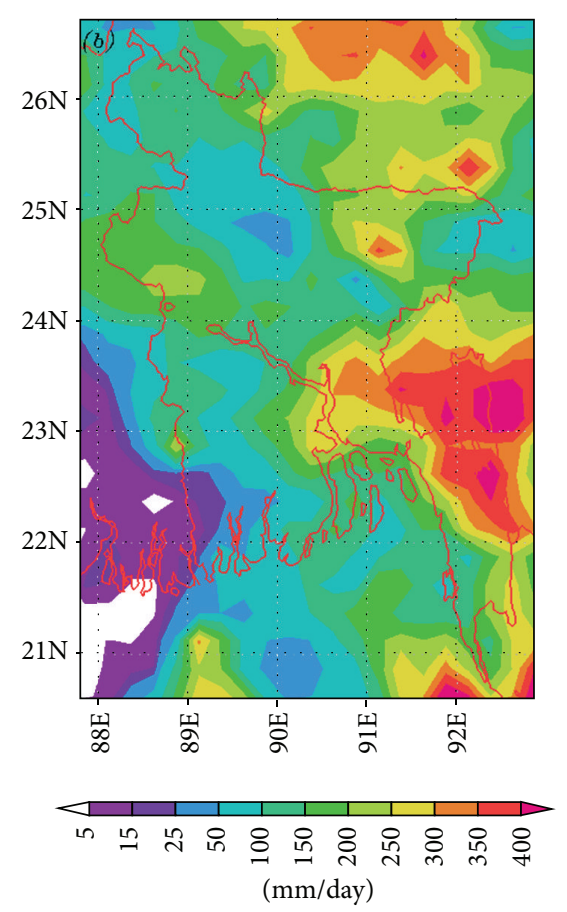

(b)

FIgURE 11: Spatial distribution of model derived $24 \mathrm{~h}$ accumulated rainfall (mm) valid for 00 UTC 22 June, 2004 (a) and TRMM 3B42V6 observed rainfall for 00 UTC 22 June, 2004 (b).

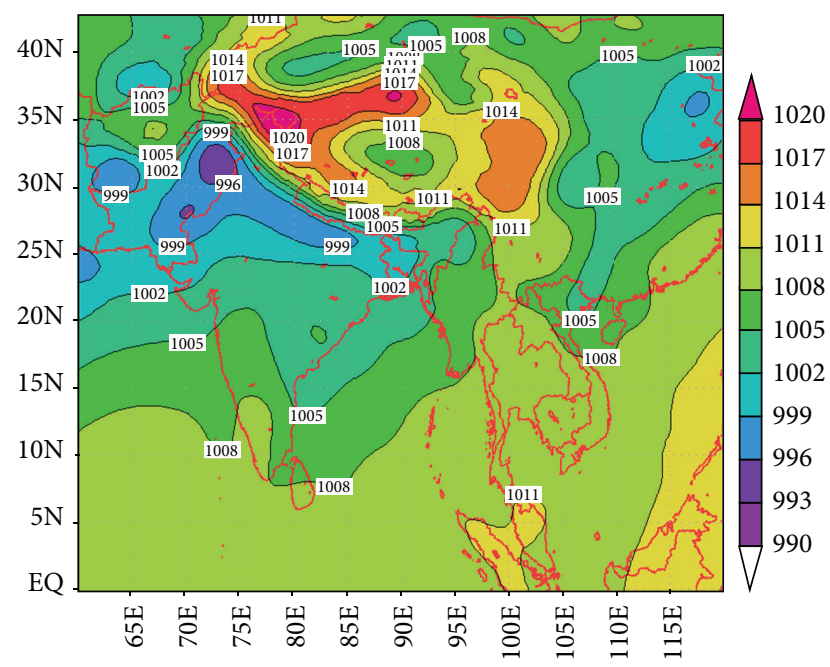

FIGURE 12: Mean sea level pressure (hPa) analysis, valid for $00 \mathrm{UTC}$ of 11 July, 2004 over South Asia.

the intensity of the model-simulated accumulated rainfall $(36.28 \mathrm{~mm})$ is higher $(19.9 \%)$ than the same observed by TRMM $(29.28 \mathrm{~mm})$, as the network of rain-gauge station in Bangladesh is not located on the passage of convective systems and the TRMM underestimated the monsoon rainfall [25] in this region. That is why the MM5 model simulated rainfall seems to be realistic.

A comparison between the two simulated events, namely, 21 June, 2004 and 11 July, 2004 based on model results and observations is given in Table 1 .

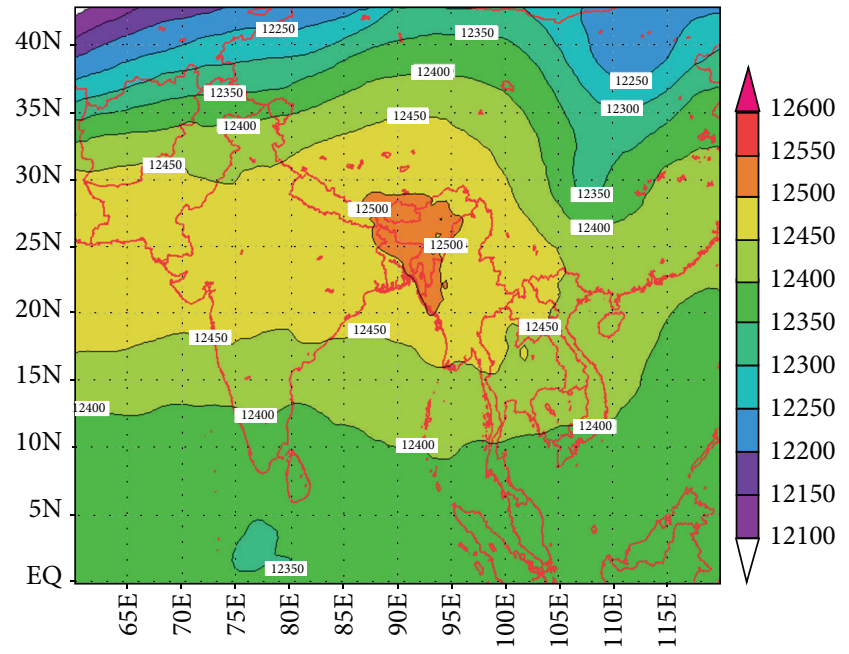

FIGURE 13: Geopotential height at $200 \mathrm{hPa}$ level, valid for $00 \mathrm{UTC}$ of 11 July, 2004 over South Asia.

The root-mean-square error (RMSE) is used to measure the prediction errors against the observed values. The RMSE of 3 hourly model rainfall with the maximum ranges of $24 \mathrm{~h}, 48 \mathrm{~h}, 72 \mathrm{~h}$, and $96 \mathrm{~h}$ predictions has been calculated with respect to the corresponding observed rainfall of the representative meteorological stations of BMD for two selected rainfall cases. The results of this RMSE are shown in Figure 20. According to the distribution of RMSE, it is found that $48 \mathrm{~h}$ prediction comes out to be the best ranging from 8 to $13 \mathrm{~mm}$ while the $96 \mathrm{~h}$ prediction shows 


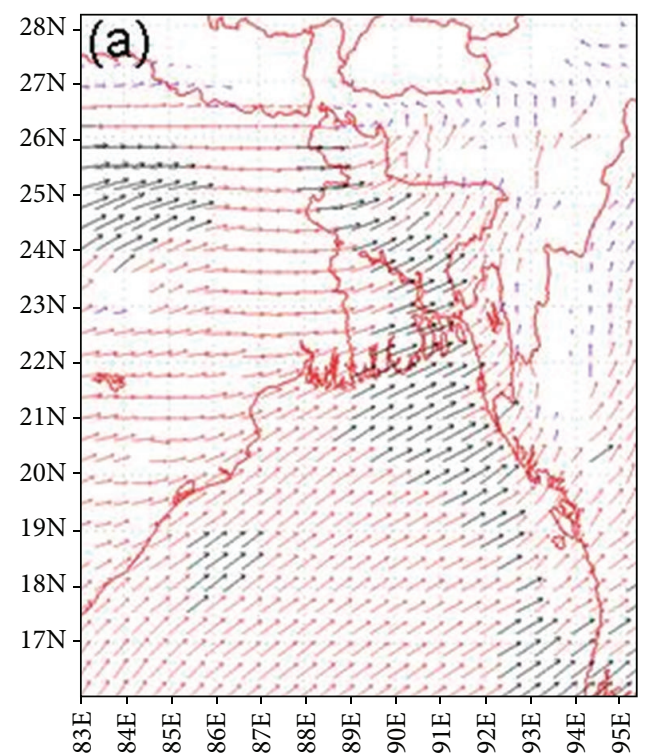

$\overrightarrow{20}$

(a)

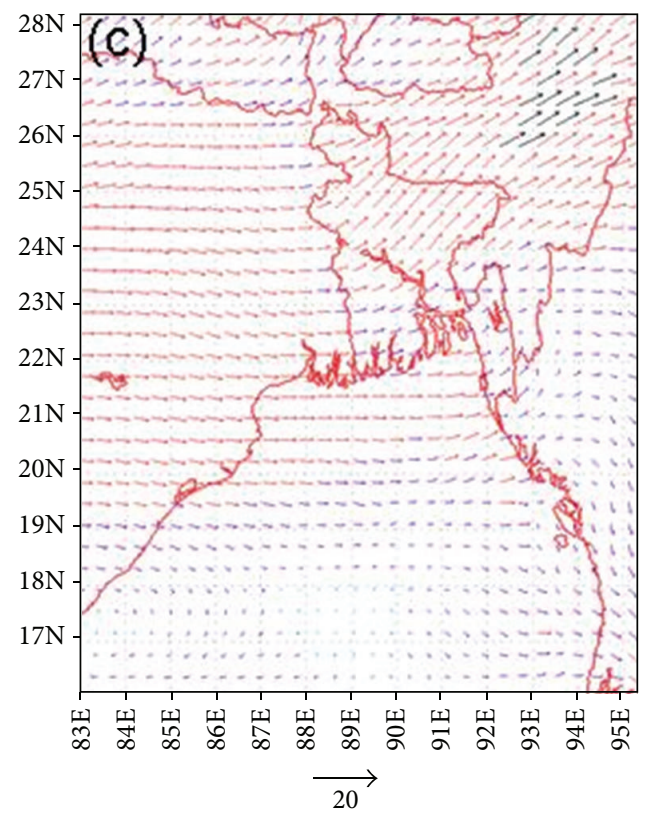

(c)

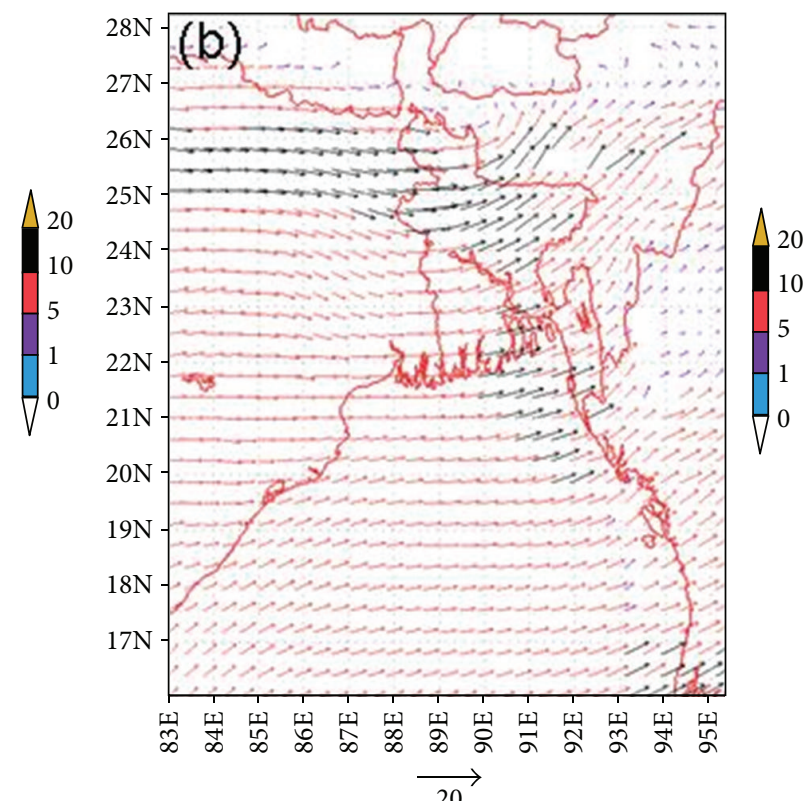

(b)

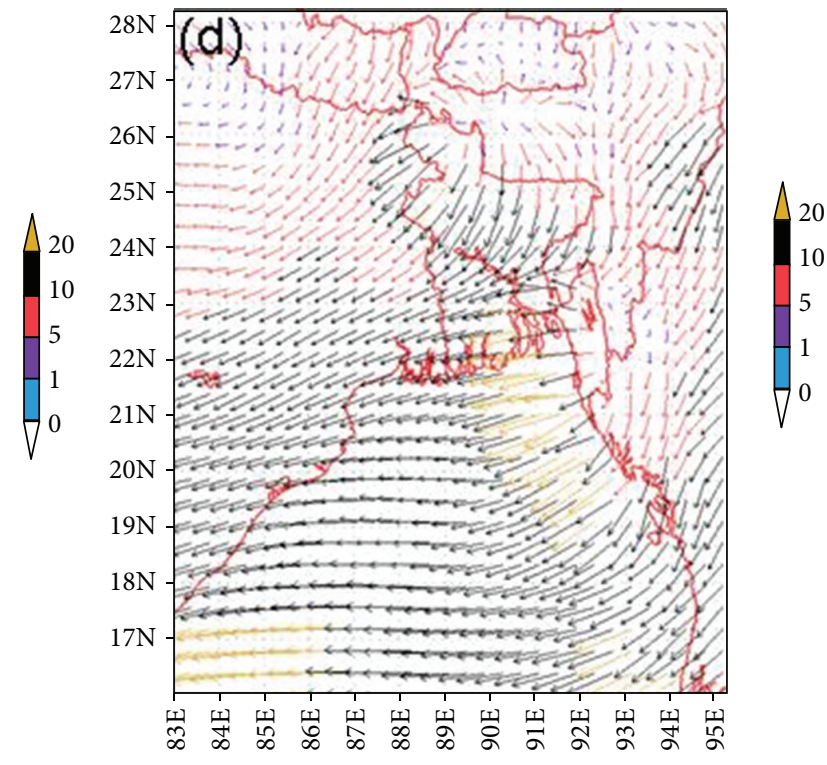

$\underset{20}{\longrightarrow}$

(d)

Figure 14: Wind field $\left(\mathrm{ms}^{-1}\right)$ analysis valid for $06 \mathrm{UTC}$ of 11 July, 2004 at $925 \mathrm{hPa}(\mathrm{a}), 850 \mathrm{hPa}$ (b), $500 \mathrm{hPa}(\mathrm{c})$, and $200 \mathrm{hPa}(\mathrm{d})$ over South Asia.

the largest error ranging from 23 to 25 . The results show that the MM5 performed well in all the $24 \mathrm{~h}, 48 \mathrm{~h}$, and $72 \mathrm{~h}$ predictions. It shows that the RMSE for $24 \mathrm{~h}$ prediction lies within $12-16 \mathrm{~mm}$ range. The prediction error is minimal for $48 \mathrm{~h}$ prediction and the error ranging from 8 to $13 \mathrm{~mm}$. The error increases thereafter for $72 \mathrm{~h}$ and $96 \mathrm{~h}$ of predictions which ranges from around $10-20 \mathrm{~mm}$ and $15-25 \mathrm{~mm}$, respectively.

\section{Conclusions}

On the basis of the present study, the following conclusions are drawn.

(1) The analysis of the mean sea level pressure field shows that the monsoon trough has been produced with realistic features oriented along east to west parallel to the foot hills of the Himalayan Mountains. The trough 
TABLE 1: Synthesized results of the synoptic analysis of the high impact rainfall events.

\begin{tabular}{|c|c|c|c|}
\hline $\mathrm{SN}$ & Parameters & Case 1: 21 Jun, 2004 & Case 2: 11 Jul, 2004 \\
\hline 1 & $\begin{array}{l}\text { Representative location of high } \\
\text { impact rainfall events }\end{array}$ & $\begin{array}{l}\text { Rangamati and neighbourhoods (southeast } \\
\text { region) }\end{array}$ & $\begin{array}{l}\text { Rangamati and neighbourhoods (southeast } \\
\text { region) }\end{array}$ \\
\hline 2 & $\begin{array}{l}\text { Position of monsoon trough (i.e., } \\
\text { pressure at m.s.l.) }\end{array}$ & $\begin{array}{l}\text { Northerly positioned compared to normal } \\
\text { which runs towards the northeast India } \\
\text { through the north of Bangladesh }\end{array}$ & $\begin{array}{l}\text { Northerly positioned compared to normal } \\
\text { and runs towards the northeast India } \\
\text { through the extreme north of Bangladesh }\end{array}$ \\
\hline 3 & Intensity of heat low & $996 \mathrm{hPa}$ & $996 \mathrm{hPa}$ \\
\hline 4 & $\begin{array}{l}\text { Pressure at the southern part of } \\
\text { India }\end{array}$ & $1011 \mathrm{hPa}$ & $1008 \mathrm{hPa}$ \\
\hline 5 & North-south pressure difference & $15 \mathrm{hPa}$ & $12 \mathrm{hPa}$ \\
\hline 6 & Winds at $850 \mathrm{hPa}$ & $\begin{array}{l}\text { Cyclonic circulation with centre over the } \\
\text { northwest Bangladesh and convergence over } \\
\text { the southeast region of Bangladesh }\end{array}$ & $\begin{array}{l}\text { Convergence and trough over the northwest } \\
\text { region of Bangladesh }\end{array}$ \\
\hline 7 & Winds at $200 \mathrm{hPa}$ & $\begin{array}{l}\text { Divergence over the southeast region } \\
\text { (Rangamati) }\end{array}$ & $\begin{array}{l}\text { Divergence over the southeast and } \\
\text { northwest region }\end{array}$ \\
\hline 8 & Jet streak at low level & $\begin{array}{l}\text { About } 30 \mathrm{~ms}^{-1} \text { ( } 58 \text { knots) over Rangamati } \\
\text { and neighbourhoods }\end{array}$ & $\begin{array}{l}\text { More than } 10 \mathrm{~ms}^{-1}(19 \mathrm{knots}) \text { over the } \\
\text { southeast region }\end{array}$ \\
\hline 9 & $\begin{array}{l}\text { Wind shear of the u component of } \\
\text { wind between } 500 \text { and } 925 \mathrm{hPa} \text { level }\end{array}$ & $\begin{array}{l}\text { Maximum over the southeastern boundary } \\
\text { of Bangladesh of the order of } 15-18 \mathrm{~ms}^{-1}\end{array}$ & $\begin{array}{l}\sim 6-9 \mathrm{~ms}^{-1} \text { over Rangamati and } \\
\text { neighbourhoods }\end{array}$ \\
\hline 10 & Low level (925 hPa) relative vorticity & $\begin{array}{l}\text { Maximum over the southeast region of the } \\
\text { order of } 30-40 \times 10^{-5} \mathrm{~s}^{-1}\end{array}$ & $\begin{array}{l}\text { Maximum of the order of } 10-20 \times 10^{-5} \mathrm{~s}^{-1} \\
\text { across the southeast region }\end{array}$ \\
\hline 11 & Low level $(925 \mathrm{hPa})$ convergence & $\begin{array}{l}\text { Maximum over Rangamati region of the } \\
\text { order of }-20 \text { to }-25 \times 10^{-5} \mathrm{~s}^{-1}\end{array}$ & $\begin{array}{l}\text { Maximum over the southeast region of the } \\
\text { order of }-15 \text { to }-20 \times 10^{-5} \mathrm{~s}^{-1}\end{array}$ \\
\hline 12 & Upper level $(200 \mathrm{hPa})$ divergence & $\begin{array}{l}\text { Maximum over the southeast region of the } \\
\text { order of } 20-25 \times 10^{-5} \mathrm{~s}^{-1}\end{array}$ & $\begin{array}{l}\text { Maximum over the southeast region of the } \\
\text { order of } 20-25 \times 10^{-5} \mathrm{~s}^{-1}\end{array}$ \\
\hline 13 & Relative humidity (925 hPa) & $\sim 90-100 \%$ over the southeast region & $\sim 90-100 \%$ over the southeast region \\
\hline 14 & Vertical extends of humidity & Up to $350 \mathrm{hPa}$ level of troposphere & $\begin{array}{l}\text { Upto } 300 \mathrm{hPa} \text { level of troposphere in a } \\
\text { narrow column }\end{array}$ \\
\hline 15 & $\begin{array}{l}\text { Amount of BMD observed rainfall } \\
\text { in } 24 \mathrm{~h}\end{array}$ & $304 \mathrm{~mm}$ at Rangamati & $337 \mathrm{~mm}$ at Rangamati \\
\hline 16 & Time of peak observed rainfall & 06 UTC & 03 UTC \\
\hline 17 & Type of the rain producing system & $\begin{array}{l}\text { Interaction of monsoon systems with trough } \\
\text { in upper level westerlies }\end{array}$ & Active monsoon condition \\
\hline
\end{tabular}

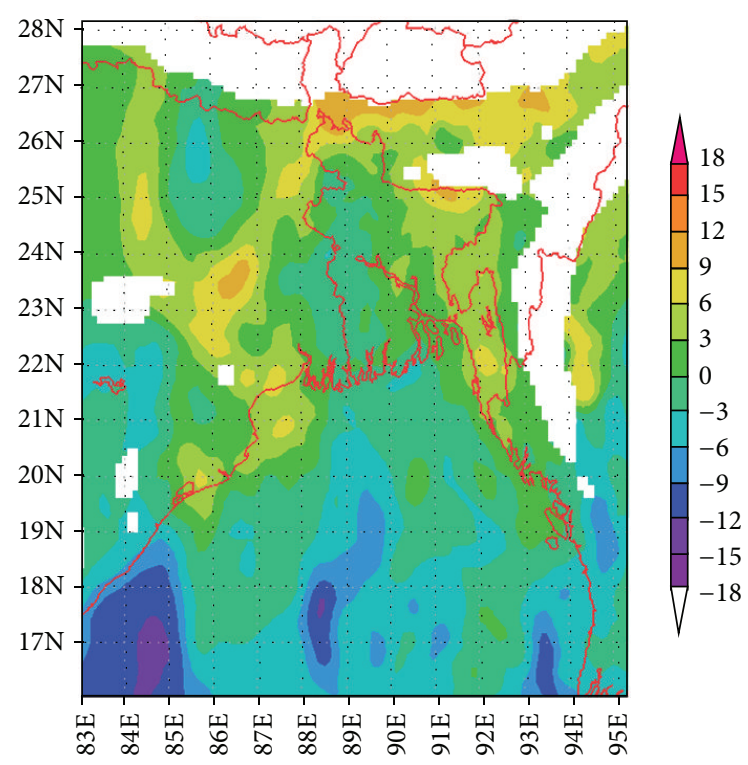

FIGURE 15: Vertical wind shear of the u component of wind $\left(\mathrm{ms}^{-1}\right)$ in the lowest $6 \mathrm{~km}$ of the atmosphere $(500-925 \mathrm{hPa})$, valid time of 06 UTC of 11 July, 2004 over South Asia.

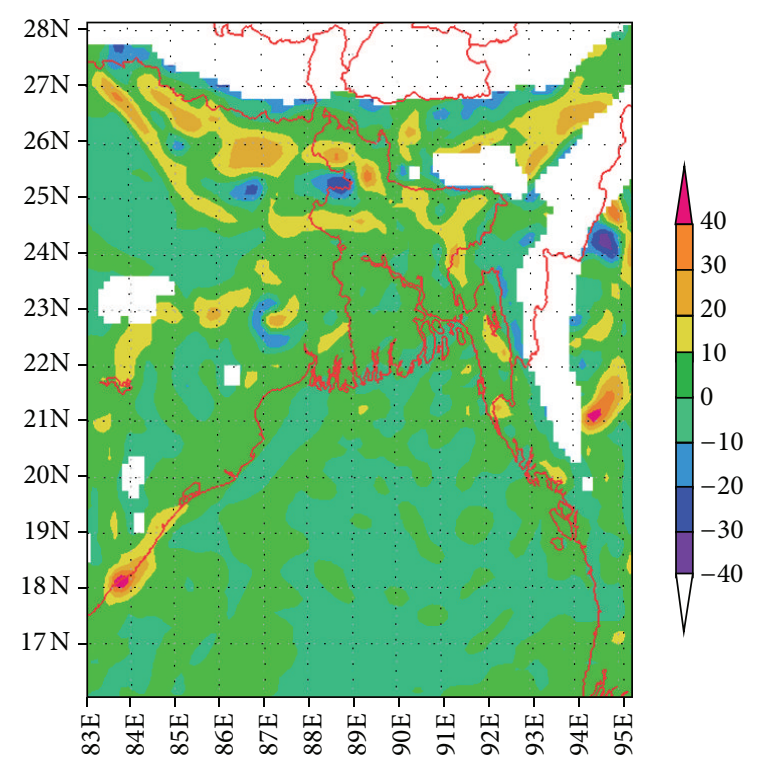

FIGURE 16: Low level relative vorticity (unit: $\times 10^{-5} \mathrm{~s}^{-1}$ ) at $925 \mathrm{hPa}$, valid for 06 UTC of 11 July, 2004 over South Asia. 


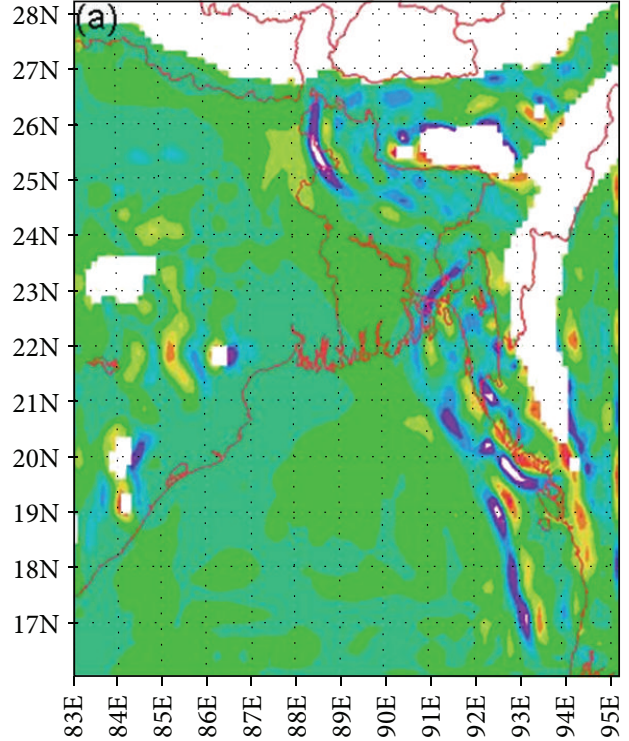

(a)

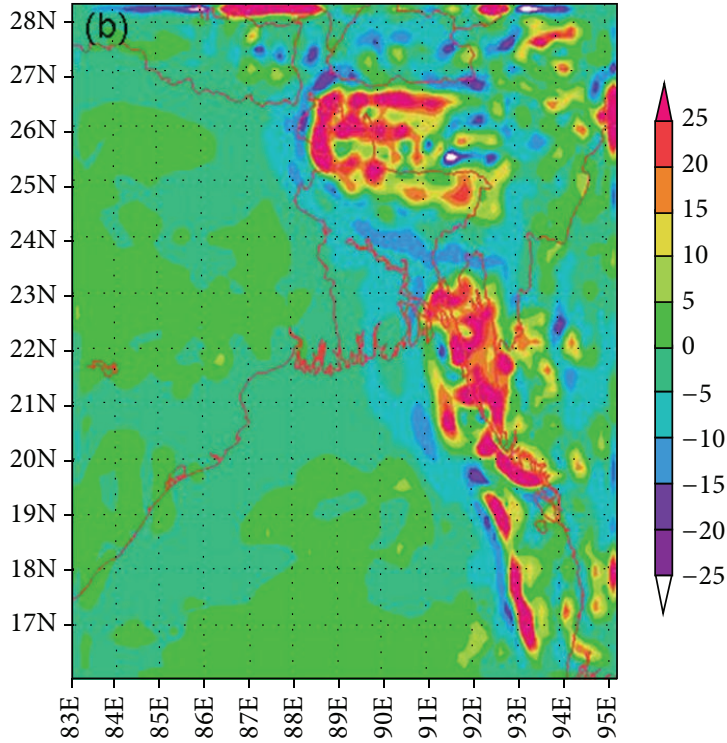

(b)

FIGURE 17: Distribution of divergence field (unit: $\times 10^{-5} \mathrm{~s}^{-1}$ ) valid for 06 UTC of 11 July, 2004 at $925 \mathrm{hPa}$ (a) and at $200 \mathrm{hPa}$ (b) over South Asia.

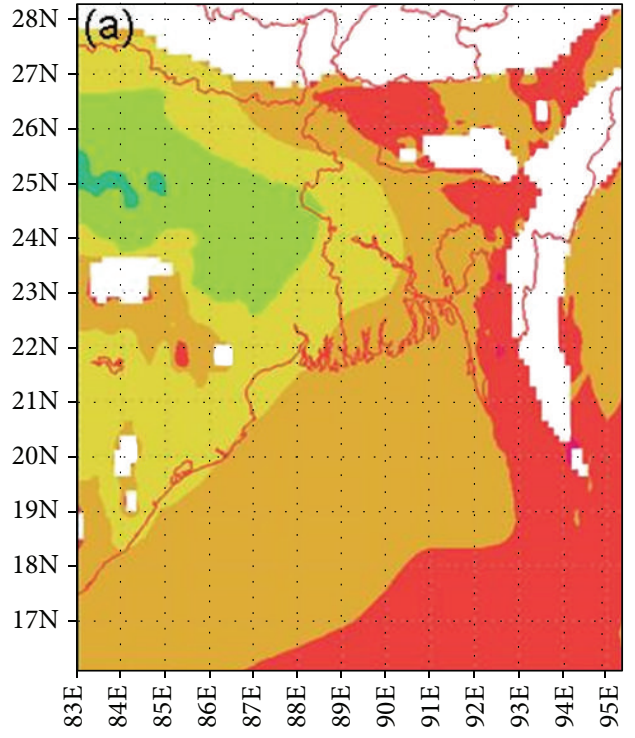

(a)

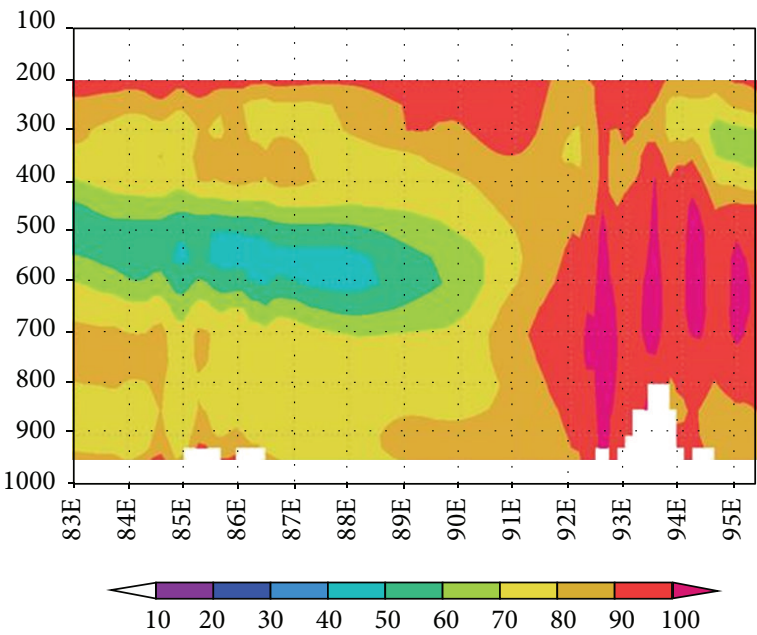

(b)

FIGURE 18: Distribution of relative humidity at $925 \mathrm{hPa}$ (a) and vertical profile of relative humidity along the latitude of Rangamati $\left(22.53^{\circ} \mathrm{N}\right)$, Bangladesh (b), valid for 00 UTC of 11 July, 2004 over South Asia.

has northerly position compared to normal and pass through Bangladesh extending up to northeast India for both cases. The heat low was found to be intense for both cases with strong north-south pressure gradient.

(2) The analysis of the $200 \mathrm{hPa}$ geopotential height field shows that the high is shifted towards south by 7 $8^{\circ}$ latitudes with axis along $22-25^{\circ} \mathrm{N}$ for both cases. The core region was found to be centered over Bangladesh covering the areas (Rangamati) where high impact rainfall had occurred. The $200 \mathrm{hPa}$ wind field shows strong outflow over this region of Rangamati.

(3) The analysis of the wind field shows that the high impact rainfall areas exhibit strong convergence of low level monsoon circulation. In both cases, the strong southwesterlies were found to exist up to $500 \mathrm{hPa}$ level. A low level jet streak varying in the range 19-58 knots in the neighbourhoods of the southeast Bangladesh is a prominent feature marking 


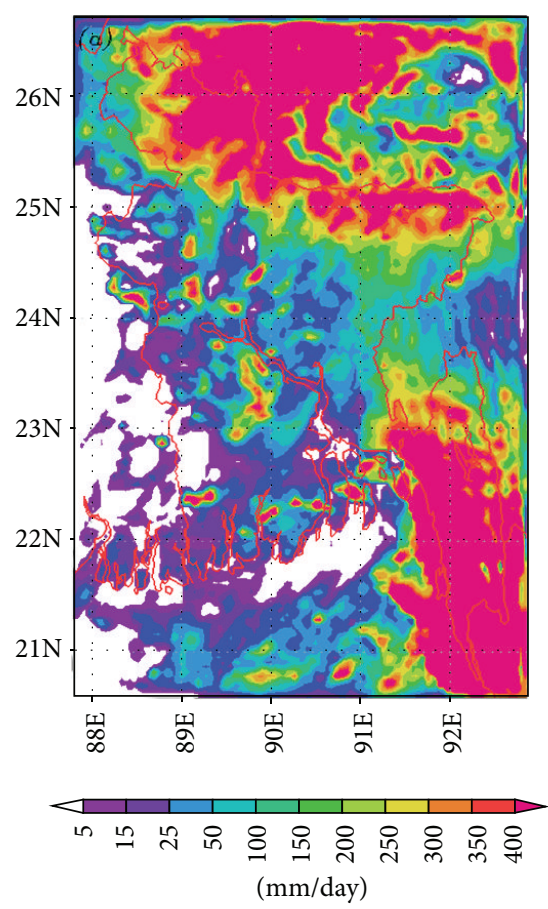

(a)

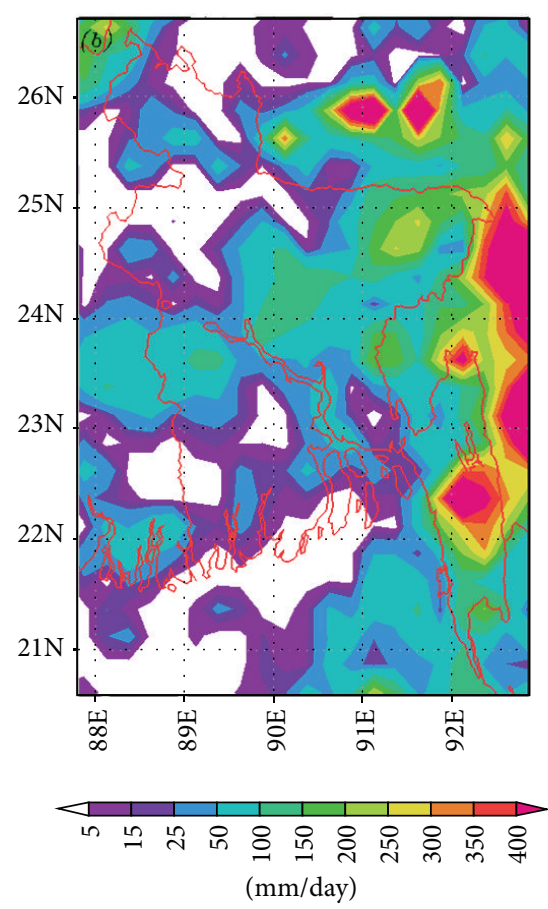

(b)

FIGURE 19: Spatial distribution of model derived $24 \mathrm{~h}$ accumulated rainfall (mm) for 00 UTC 12 July, 2004 (a) and TRMM 3B42V6 observed rainfall for 00 UTC 12 July, 2004 (b).

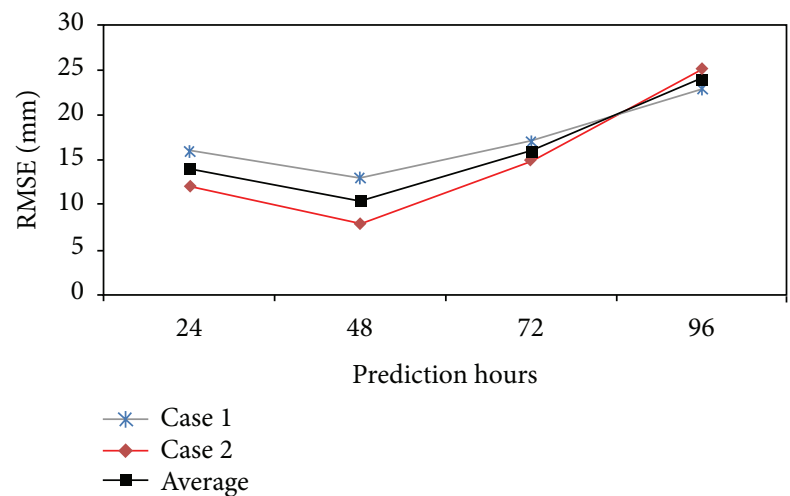

FIGURE 20: Root mean square errors (RMSE) of rainfall (mm) obtained from the MM5 model with respect to BMD observations over Bangladesh.

the strong vertical wind shear in the lower troposphere. The lower troposphere $(925-500 \mathrm{hPa})$ over the southeast of Bangladesh and neighbourhood was characterized by the strong vertical wind shear with a core of strong shear of $9-18 \mathrm{~ms}^{-1}$. This wind shear helped to develop convective systems over this region of Bangladesh.

(4) The study shows that the areas where high impact rainfall events were observed are characterized by high low level relative vorticity, strong low level convergence, and upper level divergence.
(5) The confluence of strong low level southwesterly flow causes transportation of large amount of moisture from the Bay of Bengal towards Bangladesh, especially over the areas of high impact rainfall and neighbourhoods. The large amount of moisture is advected from the Bay of Bengal which confluences in a relatively small area over Rangamati, Bangladesh, and it is a striking feature behind the strong convection over the areas of the selected cases. The high impact rainfall areas were characterized by high atmospheric relative humidity which extends up to the upper troposphere along a narrow vertical column. Usually, the humidity does not extend above $500 \mathrm{hPa}$ level during summer monsoon season over this region.

(6) The model simulation produces realistic pattern of rainfall over Rangamati and its neighbourhoods as compared with TRMM 3B42V6 observation. Model simulation using D3 domain produces details structure of the spatial patterns of rainfall over Bangladesh.

(7) According to the distribution of RMSE, it is found that $48 \mathrm{~h}$ prediction comes out to be the best ranging from 8 to $13 \mathrm{~mm}$ while the $96 \mathrm{~h}$ prediction shows the largest error ranging from 23 to 25.

Finally, it may be concluded that the Fifth-Generation PSU/NCAR Mesoscale Model MM5 version 3.7 with the right combination of the nesting domain, horizontal resolution, and the parameterization schemes is able to simulate and predict the high impact rainfall events over Bangladesh reasonably well, though there are some spatial and temporal 
biases in the simulated rainfall pattern. Associated synoptic features as simulated by the model were found to be realistic.

\section{Acknowledgments}

The authors are thankful to Dr. Someswar Das, ScientistG, NCMRWF, India, and Dr. Md. Nazrul Islam, Professor, Department of Meteorology, King Abdul Aziz University, Jeddah, KSA, for helpful suggestions and encouragement.

\section{References}

[1] A. D. Charles, "Scientific approaches for very short-range forecasting of severe convective storms in the United States of America," International Workshop on Observation, pp. 181-188, 1993.

[2] S. A. Braun and W.-K. Tao, "Sensitivity of high-resolution simulations of Hurricane Bob (1991) to planetary boundary layer parameterizations," Monthly Weather Review, vol. 128, no. 12, pp. 3941-3961, 2000

[3] P. K. Patra, M. S. Santhanam, K. V. J. Potty, M. Tewari, and P. L. S. Rao, "Simulation of tropical cyclones using regional weather prediction models," Current Science, vol. 79, no. 1, pp. 70-78, 2000.

[4] N. L. Seaman, "Meteorological modeling for air-quality assessments," Atmospheric Environment, vol. 34, no. 12-14, pp. 22312259, 2000.

[5] S. Das, "Mesoscale and cloud resolving scale simulation of a heavy precipitation episode and associated cloud system using MM5 model," in Weather and Climate Modeling, Singh, Ed., pp. 106-117, New Age International, New Delhi, India, 2002.

[6] R. K. Jenamani, S. C. Bhan, and S. R. Kalsi, "Observational/forecasting aspects of the meteorological event that caused a record highest rainfall in Mumbai," Current Science, vol. 90, no. 10, pp. 1344-1362, 2006.

[7] A. K. Bohra, S. Basu, E. N. Rajagopal et al., "Heavy rainfall episode over Mumbai on 26 July 2005: assessment of NWP guidance," Current Science, vol. 90, no. 9, pp. 1188-1194, 2006.

[8] A. J. Litta, B. Chakrapani, and K. Mohankumar, "Mesoscale simulation of an extreme rainfall event over Mumbai, India, using a high-resolution MM5 model," Meteorological Applications, vol. 14, no. 3, pp. 291-295, 2007.

[9] M. N. Ahasan and A. Q. Khan, "Simulation of a flood producing rainfall event of 29 July 2010 over northwest Pakistan using WRF-ARW model," Natural Hazards, vol. 69, no. 1, pp. 351-363, 2013.

[10] J. Thomas, J. Galarneau, M. H. Thomas, and S. W. Jeffrey, Heavy Rains and Historic Flooding Over Pakistan in Late, synoptic conditions and physical mechanisms, 2010, http://www.esrl .noaa.gov/psd/people/thomas.galarneau/index.html.

[11] P. J. Webster, V. E. Toma, and H. M. Kim, "Were the 2010 Pakistan floods predictable?” Geophysical Research Letters, vol. 38, no. 4, Article ID 046346, 2011.

[12] K. Prasad, "Monsoon forecasting with a limited area numerical weather prediction system," SMRC Scientific 11, SAARC Meteorological Research Centre (SMRC), 2005.

[13] M. N. Islam, "Studies of summer monsoon rainfall using regional climate model PRECIS," Scientific Report 22, SAARC Meteorological Research Centre (SMRC), 2008.
[14] S. Das, "Composite Characteristics of Nor'Westers observed by TRMM \& Simulated by WRF Model," SMRC Scientific Report 25, SAARC Meteorological Research Centre (SMRC), 2009.

[15] M. N. Ahasan, M. A. M. Chowdhury, and D. A. Quadir, "Prediction of high impact rainfall events of summer monsoon over Bangladesh using high resolution MM5 model," Sri Lanka Journal of Physics, vol. 12, pp. 43-58, 2011.

[16] M. N. Ahasan, M. A. M. Chowdhury, and D. A. Quadir, "Simulation of a heavy rainfall event on 14 September 2004 over Dhaka, Bangladesh using MM5 model," Journal of Scientific Research, vol. 3, no. 2, pp. 261-270, 2011.

[17] M. N. Ahasan, M. A. M. Chowdhury, and D. A. Quadir, "Simulation of a heavy rainfall event of 11 June 2007 over Chittagong, Bangladesh using MM5 model," Mausam, vol. 64, no. 3, pp. 405-416, 2013.

[18] M. N. Ahasan, K. M. Z. Rayhun, M. A. Mannan, and S. K. Debsarma, "Synoptic analysis of a heavy rainfall event over southeast region of Bangladesh using WRF model," Journal of Scientific Research, vol. 5, no. 3, pp. 421-434, 2013.

[19] G. A. Grell, J. Dudhia, and D. R. Stauffer, A Description of the 5th Generation Penn State/NCAR Mesoscale Model (MM5), NCAR/TN-398+STR, NCAR technical note, 1994.

[20] J. Dudhia, D. Gill, K. Manning, W. Wang, and C. Bruyere, PSU/NCAR Mesoscale Modeling System (MM5 VerSion 3) Tutorial Class Notes and User's Guide, National Center for Atmospheric Research, Boulder, Colo, USA, 2002.

[21] R. A. Anthes, "A cumulus parameterization scheme utilizing a one dimensional cloud model," Monthly Weather Review, vol. 105, pp. 270-286, 1977.

[22] S.-Y. Hong and H.-L. Pan, "Nonlocal boundary layer vertical diffusion in a medium-range forecast model," Monthly Weather Review, vol. 124, no. 10, pp. 2322-2339, 1996.

[23] J. Dudhia, "Numerical study of convection observed during the Winter Monsoon Experiment using a mesoscale twodimensional model," Journal of the Atmospheric Sciences, vol. 46, no. 20, pp. 3077-3107, 1989.

[24] D. A. Quadir, M. A. Hussain, and M. N. Ahasan, Climatic Characteristics of Temperature and Precipitation of Bhutan, vol. 58, no. 1, MAUSAM, 2007.

[25] M. N. Islam and H. Uyeda, "Use of TRMM in determining the climatic characteristics of rainfall over Bangladesh," Remote Sensing of Environment, vol. 108, no. 3, pp. 264-276, 2007. 

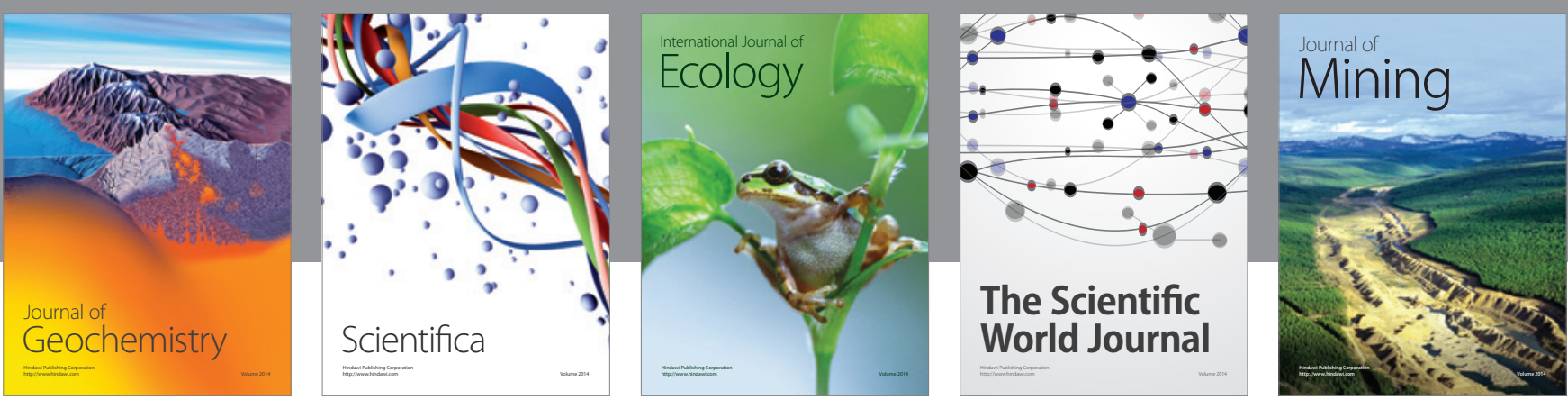

The Scientific World Journal
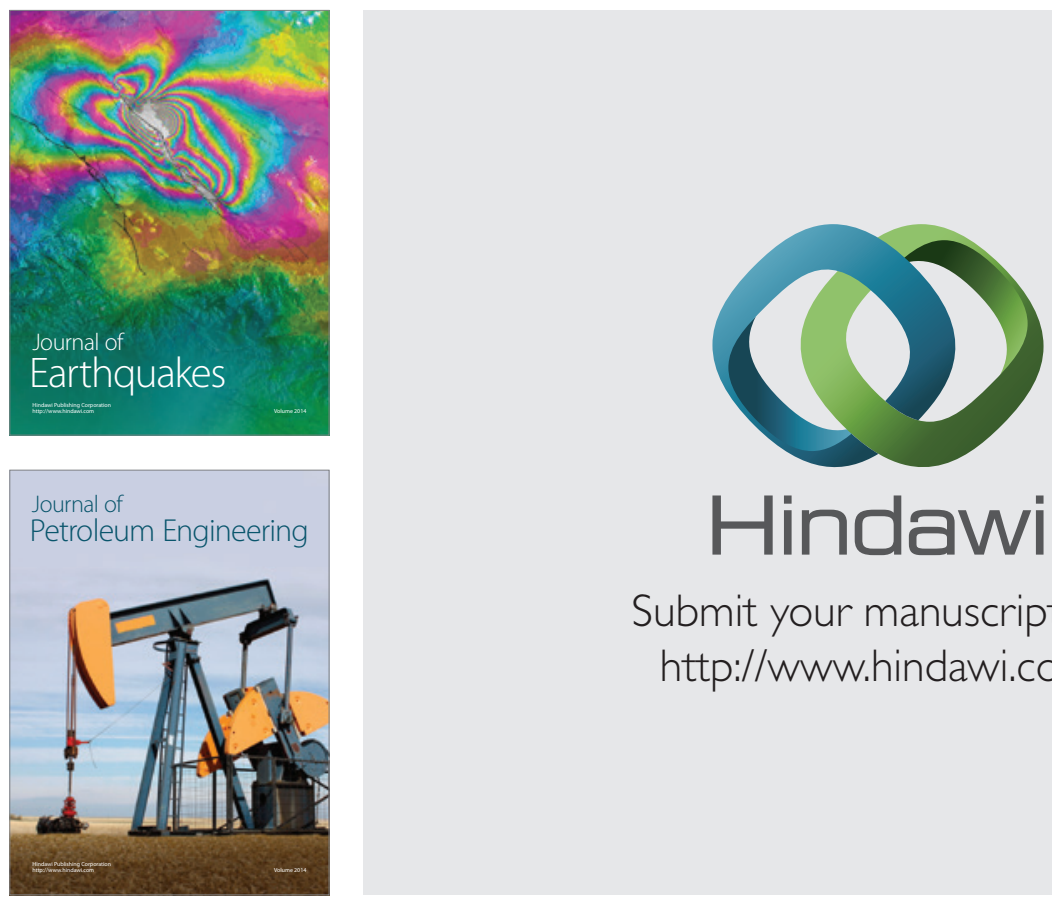

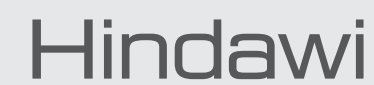

Submit your manuscripts at

http://www.hindawi.com
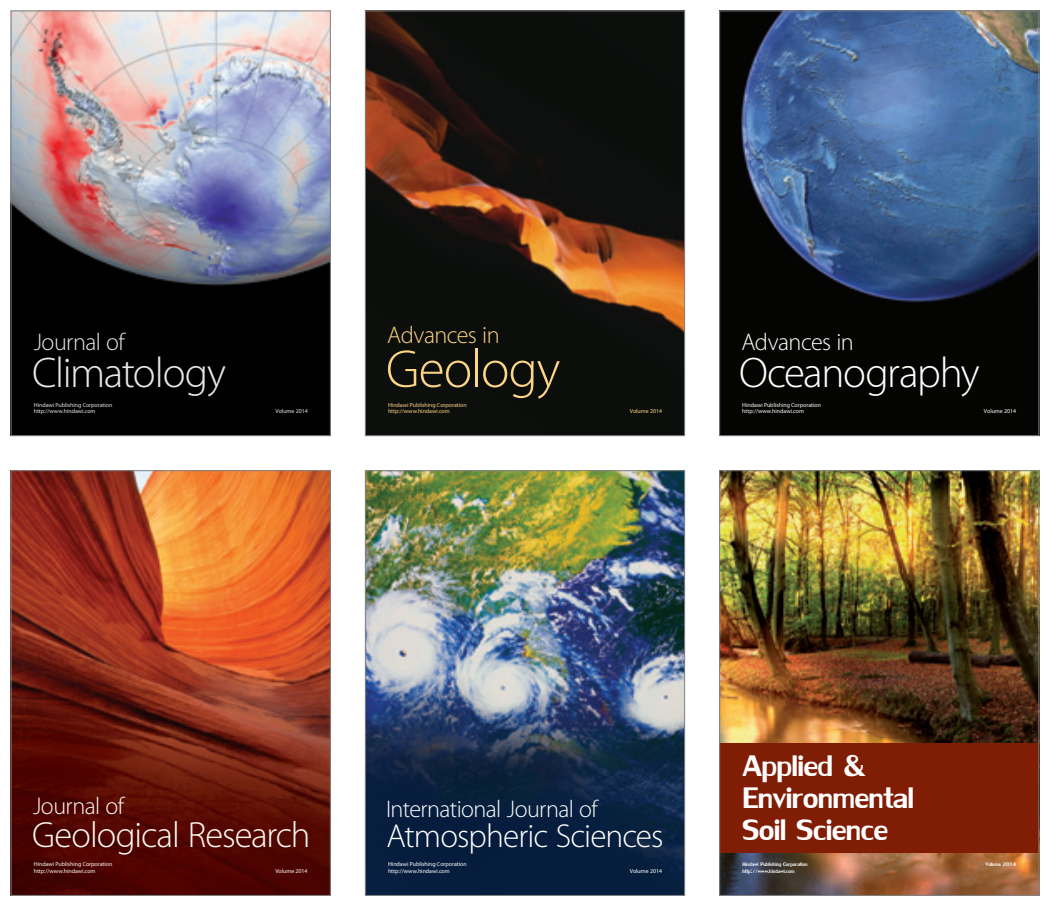
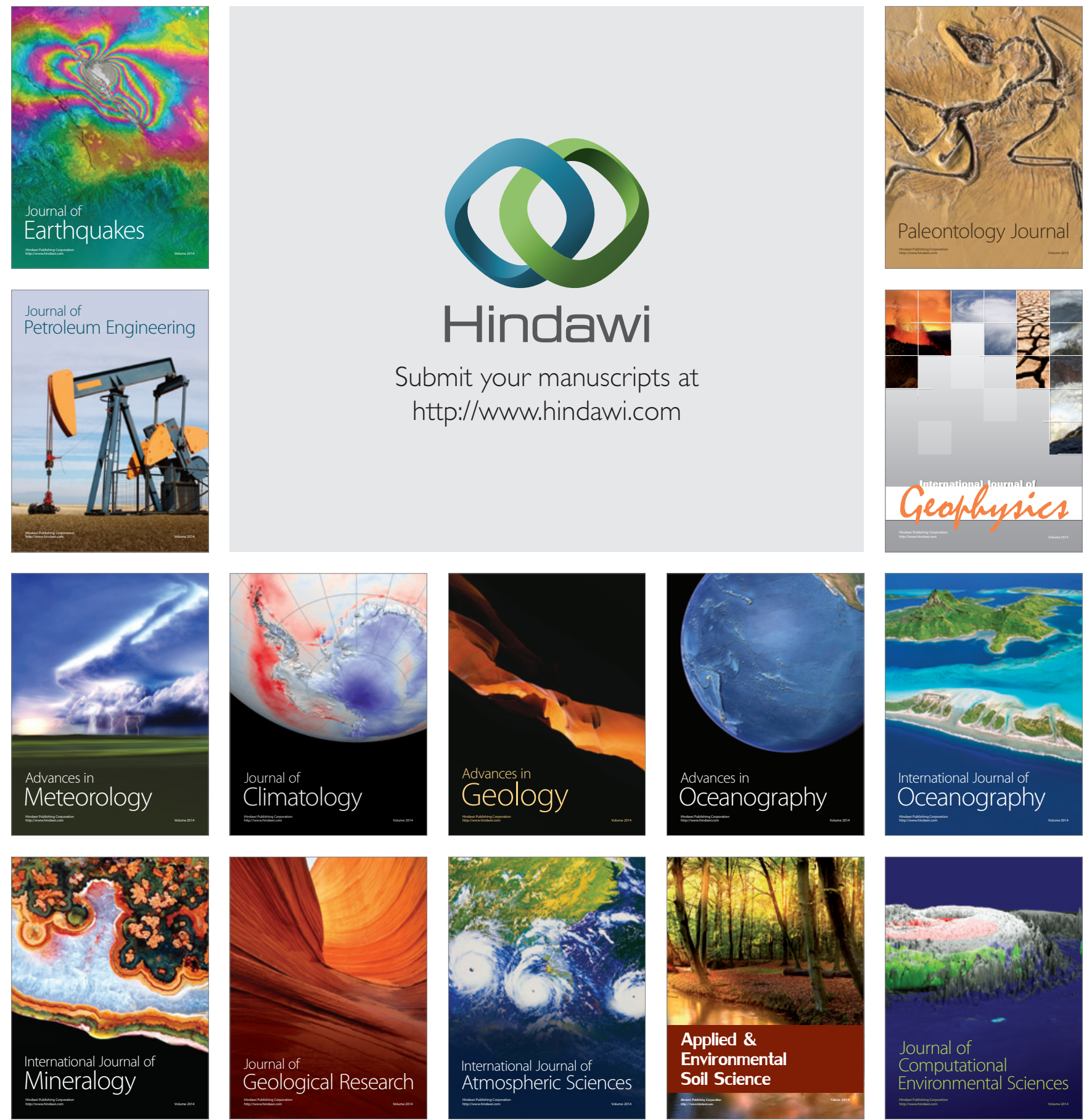